\title{
Monetary Conditions and Banks' Behaviour in the Czech Republic
}

\author{
Adam Geršl, Petr Jakubík, Dorota Kowalczyk, Steven Ongena, \\ and José-Luis Peydró Alcalde
}

24th February 2015

\begin{abstract}
This paper examines the impact of monetary conditions on the risktaking behaviour of banks in the Czech Republic by analysing the comprehensive credit register of the Czech National Bank. Our duration analysis indicates that expansionary monetary conditions promote risk-taking among banks. At the same time, a lower interest rate during the life of a loan reduces its riskiness. While seeking to assess the association between banks' appetite for risk and the short-term interest rate we answer a set of questions related to the difference between higher liquidity versus credit risk and the effect of the policy rate conditioned on bank and borrower characteristics.
\end{abstract}

\section{Introduction}

One of the factors often mentioned as a cause of the recent financial turbulence has been the relaxed monetary policy of major central banks, which might have increased financial institutions' appetite for risk. Existing theoretical work shows how changes in short-term interest rates may affect risk-taking by financial institutions, and empirical studies that followed to a large effect confirmed the theoretical concepts.

\footnotetext{
*Adam Geršl, Joint Vienna Institute, Czech National Bank, and Institute of Economic Studies, Charles University in Prague (Corresponding Author: adam.gersl@gmail.com); Petr Jakubík, EIOPA, Czech National Bank, and Institute of Economic Studies, Charles University in Prague; Dorota Kowalczyk, CERGE-EI, Prague, and RANEPA, Moscow; Steven Ongena, University of Zurich, Swiss Finance Institute, and CEPR; José-Luis Peydró Alcalde, Universitat Pompeu Fabra, Department of Economics and Business. This work was supported by the Czech National Bank (Research Project No. C4/2009) and the Grant Agency of the Czech Republic (project GA CR No. 403/10/1235). The authors thank Dana Hájková, Štěpán Jurajda, Xavier Freixas and two anonymous referees for useful comments, and Josef Brechler and Thomas Mitterling for excellent assistance. The opinions expressed in this article are only those of the authors and do not represent the official views of the institutions with which the authors are affiliated.
} 
This paper concentrates on the effect of monetary conditions on bank risk taking in the Czech Republic, a country where the banking sector has undergone tremendous changes since the 1990s with respect to regulatory policy and banks' attitude towards corporate lending and credit risk assessment. It is an interesting case for analysis as it is a small open economy with independent monetary policy and with a banking sector dominated by foreign ownership. Furthermore, the empirical analysis was enabled by the availability of loan-level data on corporate borrowers, which is critical to assess the link between monetary policy stance and credit risk.

We focus on two distinct questions, namely whether a monetary easing leads to more lending to borrowers with a riskier past and whether it encourages banks to extend riskier new loans. To examine how the monetary conditions affect banks' appetite for credit risk along this two separate dimensions, we model the probability of accepting borrowers with a bad credit history within a probit framework and the time to loan failure within a survival analysis framework in association with the short interest rate and a set of other macroeconomic, firm, loan and bank characteristics.

Estimating the impact of short-term interest rates on banks' risk taking should enhance the understanding of the link between monetary policy and financial stability in the Czech Republic. This link has been explored using macroeconomic modelling, VAR methodology and bank-by-bank stress testing (e.g. Babouček and Jančar (2005), Čihák and Heřmánek (2005), and Jakubík and Schmieder (2008)) as well as validation of credit risk (rating) models on a simulated corporate loan portfolio of the Czech banking sector (Kadlčáková and Keplinger, 2004). However, our study is the first to apply panel data analysis on macroeconomic, bank, loan and borrower data to study the link between monetary conditions and financial stability from the perspective of banks' attitude to credit risk and its sensitivity to the short-term interest rates. In contrast to other studies, which investigate the link between asset quality and macroeconomic indicators for a panel of countries (e.g. Nkusu (2011), or Glen and Mondragón-Vélez (2011)) we employ a unique microlevel dataset obtained from the Czech National Banks' Credit Register. Moreover, most studies focus on the advanced economies, while we explore theses linkages for an emerging market economy.

This paper is organized as follows. The following section reviews the relevant literature and sets the hypotheses to be tested, and is followed by a section which outlines the methodology and model specification. Section 4 describes the dataset, while Section 5 presents the estimation results and provides robustness checks. Section 6 summarizes and concludes. 


\section{Review of literature and hypotheses}

Monetary policy influences bank behaviour and the supply of loans via several channels (Bernanke and Gertler, 1995). Because of imperfect information, incomplete contracts and imperfect bank competition, monetary policy may affect loan supply. In particular, expansive monetary policy may increase bank loan supply either directly (the bank lending channel) or indirectly by improving borrower net worth and, hence, by reducing the agency costs of lending (the balance sheet channel). In the "balance sheet channel", higher interest rates, by reducing borrower net worth, may induce a flight to quality from financiers (Bernanke, Gertler, and Gilchrist, 1996) or more lending to borrowers with more pledgeable assets (Matsuyama, 2007). On the other hand, when there is a reduction of overnight rates, financiers start lending more to borrowers that previously had a too-low net worth (hence, too-high agency costs of lending), because thanks to the lower rates their net worth rises enough to make lending possible. However, in this case, the potential softening of credit standards is not regarded as greater bank appetite for risk induced by low rates.

Recent theoretical work shows how changes in short-term interest rates may affect risk-taking by financial institutions. This effect has been labelled the "risk-taking channel" of monetary policy following Borio and Zhu (2007) and can be considered a part of the credit channel Diamond and Rajan (2006), and Stiglitz and Greenwald (2003). Borio and Zhu (2007) advocate that the policy rate may affect the risk tolerance of banks due to increased wealth or the presence of "sticky" targets for rates of return. The latter transmission mechanism is quite self-explanatory. Banks targeting rigid rates of returns would reach out to riskier borrowers to recoup their drop in profits at times of monetary expansion. The former argument rests upon the conjecture that, in general, the risk tolerance of any economic agent increases with wealth. Such an effect can be found, for instance, in the mean-variance portfolio framework, where investors become less risk-averse during economic expansions because their consumption increases relative to its normal level (Campbell and Cochrane, 1999). If risk aversion decreases with wealth, lower interest rates may in turn induce more risk-taking among banks by augmenting asset and collateral values.

Furthermore, lower interest rates may reduce the threat of deposit withdrawals (Diamond and Rajan, 2006), reduce adverse selection problems in credit markets (Dell'Ariccia and Marquez, 2006), improve bank net worth (Stiglitz and Greenwald, 2003), or lead to a search for yield (Rajan, 2006), allowing banks to relax their credit standards. This softening happens not only for riskier loans, which have an adjusted net present value (NPV) close to zero, but also for average loans. On the other hand, higher interest rates increase the opportunity cost of holding cash for banks, thus making risky alternatives more attractive (Smith, 2002). Higher interest rates could also reduce bank net worth down to a point where a "gambling for resurrection" strategy becomes attractive (Kane (1989), and Hellman, Murdock, and Stiglitz (2000)). Given the conflicting the- 
oretical implications, the impact of short-term interest rates on risk-taking is ultimately a critical empirical question.

Theoretical advancements in the field of monetary policy and bank risk interaction, together with recent economic developments, have invigorated the related empirical work. Altunbas, Gambacorta, and Marques-Ibanez (2009) reexamines the monetary policy transmission mechanism in the euro area and, contrary to previous studies, accounts for the role of bank risk. However, Altunbas, Gambacorta, and Marques-Ibanez (2009) concentrates on the influence of bank risk on the credit supply and not risk tolerance as such. In contrast, Altunbas, Gambacorta, and Marques-Ibanez (2010) examines banks' risk responses to changes in the monetary policy indicator. The study concludes that low interest rates increase bank risk, but employs solely bank-level and macroeconomic data. The renewed interest has also fuelled research of bank lending standards. Lown and Morgan (2006) estimates a VAR model for credit standards, lending volumes and output fluctuations in order to examine the role of lending frictions on the two latter quantities. The authors find that fluctuations in commercial credit standards significantly explain changes in bank loan supply and real GDP. Maddaloni, Peydró-Alcalde, and Scope (2009), on the other hand, assesses the impact of monetary policy on bank lending standards and establishes that lower interest rates lead to softening bank credit standards.

To the best of our knowledge, the first empirical investigations of the impact of monetary policy on bank risk-taking behaviour are due to Ioannidou, Ongena, and Peydró-Alcalde (2007) and Jiménez, Ongena, Peydró-Alcalde, and Saurina (2008). The latter tests the effect of interest rates on banks' appetite for credit risk on Spanish data, while the former explores this question using the credit register from Bolivia. Both papers find that in the short run a lower short-term interest rate augments banks' appetite for risk, while the medium-term effect is a decrease in credit risk for existing bank portfolios. In the longer term, both effects yield a net increase in the risk incurred. The analysis of Bolivian banks' appetite for risk is further advanced in Ioannidou, Ongena, and Peydró-Alcalde (2009), where the authors additionally explore the pricing of credit risk.

This study poses two main and distinct research questions that relate the monetary policy stance and bank risk-taking. First, we examine whether lower interest rates promote more lending to borrowers with a riskier past. Such an effect is likely to be attributed to higher current net worth of borrowers. Second, we investigate whether lower interest rates encourage banks to incur more risk by accepting borrowers with a higher probability of default. Default is defined as failure to pay a loan instalment and/or interest 90 or more days past the due date. Risky past stands for other overdue loans prior to the origination of a new loan. In addition to these two main questions, we also test how bank capital, liquidity, and lending strategy diversification influences risk taking.

Most studies exploring the theoretical mechanisms that could be directly or indirectly linked to the "risk-taking channel" suggest that banks should be more reluctant to grant risky loans at times of monetary contraction. Thus, we hy- 
pothesize that lower interest rates imply more credit risk-taking along both dimensions mentioned above, i.e. granting loans to borrowers with riskier past and granting loans to borrowers with a higher probability of default. Naturally, in the econometric analysis we expect a negative sign on the estimated coefficient on the interest rate prior to loan origination. This negative relation can be attributed to weaker incentives to screen borrowers when interest rates that determine banks' financing costs are low (Dell'Ariccia and Marquez, 2006). Lower interest rates decrease financing costs, thus banks' motivation to screen borrowers declines, which in turn may result in them accepting riskier applicants. Another reason could be a reduced threat of deposit withdrawals at times of excess liquidity, as in Diamond and Rajan (2006). Lower interest rates generate more liquidity in the banking sector, which provides less of an incentive for depositors to withdraw and more of an incentive for banks to finance risky projects. Thus, our two main research hypotheses caim that monetary policy stance affects credit risk, in particular:

H 1 Lower interest rates lead to more lending to borrowers with a riskier past.

H 2 Lower interest rates encourage banks to incur more risk by accepting not only borrowers who are riskier ex ante, but also those with a higher probability of default per time period.

It is reasonable to assume that a bank's risk tolerance might vary with its economic profile. Typically, the theoretical banking literature links a bank's riskiness with its level of capital and, as in Keeley (1990), predicts a negative relation between the two. Note, however, that the theory concentrates on bank capital and default risk, not risk tolerance. Moreover, in a banking sector shared between few banks, a highly capitalized bank might easily become "too big to fail". Due to this moral hazard problem, banks rich in capital may engage in riskier lending at times of monetary expansion. On the other hand, the Czech banking sector is not only concentrated, but also dominated by foreign capital, and foreign capital usually induces more monitoring effort. In short, the effect of bank capital is not easily foreseeable and we expect any outcome, albeit an insignificant one.

H 3 Banks' capital significantly influences and differentiates their risk-taking behaviour in response to monetary and macroeconomic changes.

Bank liquidity is another characteristic likely to differentiate a bank's attitude to risk in low and high interest rate regimes. Diamond and Rajan (2006) develop a model of the "liquidity channel", as a modification of the "lending channel", and obtain that banks accumulating liquid assets tend to grant less risky loans. In our hypothesis we test their implications.

H 4 Banks with a poorer liquidity profile tend to take more risk in lowerinterest-rate periods. 
Finally, economic theory provides us with contradicting suggestions about the optimal strategy and, thus, loan portfolio composition. The literature on intermediation following Diamond (1984) promotes diversification as a way of minimizing the risk of failure. In doing so, such authors use the argument of uncorrelated returns in line with Markowitz (1952) portfolio theory. On the other hand, the corporate finance literature argues that specializing may lead to improvement in a bank's monitoring effectiveness and incentives, and thus is likely to reduce credit risk (Stomper, 2006). Nevertheless, we formulate our hypothesis based on studies on financial intermediation, and expect less risk-taking among more diversified banks.

H 5 A lending strategy based on diversification, ceteris paribus, limits banks' risk appetite.

\section{Methodology and Model Specification}

This study considers two different measures of credit risk-taking. First, we estimate the likelihood that a borrower with observable past non-performance obtains a new loan. We treat all firms with overdue loans six months prior to new loan origination as borrowers with a bad credit history and, thus, ex-ante riskier. The dependant variable in our probit model $^{1}, B_{\text {Bd }}$ history, equals one for the ex-ante riskier borrowers. We explain the probability that a borrower with a "bad history" receives a loan, conditioning on selected bank, loan, firm and macroeconomic variables. Among those explanatory variables, the interest rate prior to loan origination is of primary interest to us. Consequently, within the probit framework we explore whether lower interest rates lead to more lending to borrowers with a riskier past $(H 1)$ and estimate the following model:

$$
P(\text { Bad history }=1 \mid X)=\Phi(\mathbf{X} \beta+\mathbf{e})
$$

where:

Bad history $=1$ if a borrower had overdue loans 6 months prior to new loan initiation

$\Phi($ ) - the standard normal cumulative distribution function

$X$ - a set of macroeconomic, bank, borrower and loan-related regressors

The other measure of credit risk-taking employed in this paper is the timespecific likelihood of loan default. Default is defined as failure to pay a loan instalment and/or interest 90 or more days past the due date. By time-specific

\footnotetext{
${ }^{1}$ A situation of a binary choice - a borrower with or without a bad history - calls for a discrete choice model such as probit.
} 
likelihood we mean the probability that loan default occurs within a specific time-span. Such a treatment emphasizes that there is a dynamic element to loan performance and that defaults differ at different points of the loan "life". After all, the loan survival time, i.e. the time for which the borrower has managed to pay regularly, affects the risk of default in the following period. By incorporating duration dependence we do not ignore the data on regular loans that eventually become nonperforming. On the contrary, all the available information helps us to determine the credit default risk at each point in the loan "life" (see Kiefer (1988)). Our methodology follows Shumway (2001), Chava and Jarrow (2004) and Duffie, Saita, and Wang (2007), who strongly advocate the importance of duration in bankruptcy predictions. Moreover, including duration dependence enables us to differentiate between the effects of monetary policy on new and outstanding loans. Finally, Matsuyama (2007) and Dell'Ariccia and Marquez (2006) show that monetary policy influences risk-taking and also lending standards and, thus, maturity. Ideally, to disentangle credit risk from liquidity risk, or the maturity effect, one should employ a measure of default probability normalized per period of time. The duration model offers such a dynamic measure of risk, namely the hazard rate. The same treatment of timespecific credit risk-taking is employed in Jiménez, Ongena, Peydró-Alcalde, and Saurina (2007) and Ioannidou, Ongena, and Peydró-Alcalde (2009), making the results of all three studies comparable.

The hazard function is the limiting probability of default in a given interval conditional on the loan having survived until this period, divided by the width of the period. Duration, i.e. the length of time a loan is performing, is also referred to as spell length $(t)$. In general, the hazard function depends on the survival probability and the density function associated with the distribution of the spells, $f(t)$. When estimating hazard functions, it is convenient to assume a proportional hazard specification with the baseline hazard $\lambda_{0}(t)$ a function of $t$ alone. This paper follows the Cox semi-parametric approach, which specifies no shape for the baseline hazard function (Cox, 1972). Therefore, we model the time to loan default, $T$, using a set of macroeconomic, bank, borrower and loan-related regressors $(X)$ within the following framework:

$$
\lambda(t)=\lambda_{0}(t) \exp \left(f\left(X, X(\tau) ; \beta, \beta^{\tau}\right)\right)
$$

where:

$X$ - characteristics constant over time

$X(\tau)$ - time-varying covariates

$\beta$ and $\beta^{\tau}$ - parameters (including time-varying variables)

$t$ - loan spell

$\tau$ - calendar time

The regressors are described in detail in the data section. The main regressor of interest, namely the short term interest rates capturing the monetary policy 
stance, is instrumented in both approaches due to the presence of the possible endogeneity problem between credit risk and domestic short-term rates (domestic monetary policy may itself react to the changes in the level of credit risk in the domestic banking system). As we use flow sampling and consider only new loans, our data does not suffer from left censoring. The right censoring problem is alleviated in a standard way, that is by expressing the log-likelihood function as a weighted average of the sample density of completed duration spells and the survivor function of uncompleted spells. We estimate four duration models and contrast their outcomes. The survival models differ in line with the shifting focus of our analysis. Each formulation contains the core covariates, namely a set of macroeconomic variables to control for major economic developments in the Czech Republic. First of all, we explore how risk-taking varies with bank characteristics. The role of banks' balance sheets (Matsuyama, 2007) and moral hazard problems (Rajan, 2006) in determining the sensitivity of bank risk-taking to monetary policy is well-established in the theory. Initially, we account for banks' heterogeneity ${ }^{2}$ by applying shared frailty duration analysis (Model I). The shared frailty effect is estimated along with the other model parameters, and the random effects are common among groups of loan spells of the same bank. A comprehensive introduction to frailty and shared frailty duration analysis is provided in Gutierrez (2002). In the next formulation (Model II), we incorporate bank characteristics and thus capture the variety across banks in their risk-taking reactions to changing monetary conditions. Naturally, banks tend to differ in their lending strategies and thus their loan portfolio diversification may impact on their risk behaviour in different interest rate regimes. Therefore, the specification for Model IV incorporates additionally the Hirschman-Herfindahl Index (hereof: $H H I$ ) as a measure of bank loan portfolio diversification.

By introducing firm and loan characteristics in Model III we control for changes in the loan and borrower pools throughout the time span of our study. More importantly, we hope to separate credit supply and demand effects. As we examine bank risk-taking, we need to identify whether the observed increases in riskier loans are supply-driven. On the other hand, bad borrowers seeking more credit when rates are low could also cause higher loan hazard rates. The difference is that with a demand-driven increase in hazardous loans the risk premiums should also rise, while the supply effect should cause a drop in the risk premiums. Ideally, we would test how risk "pricing" reacts to changes in monetary conditions in the Czech banking sector and identify either the supply or demand effect. However, that requires data on loan pricing, specifically each loan contract interest rate, and the Central Credit Register maintained by the Czech National Bank does not record such data. The second-best empirical strategy is to control for the quality of borrowers throughout the time span and for those loan characteristics which are regarded by financial intermediation theory as screening devices. The role of loan size and collateral as intermediary screening devices is grounded in the theory. Loan maturity also plays some role

\footnotetext{
${ }^{2}$ Generally, when controlling for unobserved heterogeneity we follow the flexible approach of (Heckmann and Singer, 1984).
} 
in disentangling supply and demand effects, as banks taking more risk will not mind engaging in long-term financing. This is no longer true for a demanddriven rise in loan riskiness.

Finally, we note that this study examines two distinct research questions relating bank risk-taking to the monetary policy stance, uses two different measures of risk-taking (the likelihood of financing an ex-ante riskier borrower and the time-specific loan default risk) and subsequently estimates two different models - a probit model and a duration model. Obviously, the outcomes of the two examinations are not comparable. Still, one would expect to see low interest rates promoting either more risk-taking in both cases or less risk-taking in both cases. However, this is not what our results for the Czech banking sector suggest. We come back to this issue when discussing the outcome of our estimations.

\section{Data}

\subsection{Data Sources}

The dataset used in this study contains 207,356 loan-period observations. The data on loans is combined with information from bank financial reports and, where available, from the financial statements of borrowers. We consider solely corporate loans for non-financial firms. In addition, we complete the dataset with macroeconomic variables describing the performance of the Czech and euro area economies. Prior to any analyses our dataset was anonymized.

The loan data comes from the Czech National Bank's Central Credit Register (CCR). Out of all the borrowers issued with loans between October 2002 and January 2010 we select a random sample amounting to $3 \%$ of all companies granted new loans in this period. ${ }^{3}$ The CCR was launched in October 2002, so this is the first available month for the loan data. The information on borrowers is obtained from two sources: the CCR and the Magnus database maintained by CEKIA. The time span for the firms' financials is also limited by data availability and covers the period from January 2000 to December 2009. We discuss the two data sources in greater detail below. The bank covariates originate from the Czech National Bank's (CNB) internal database. Clearly, the scope of the central bank's knowledge about the economic situation of each "supervised" bank is quite broad. In our analysis we limit ourselves to the key bank performance variables and the bank ownership type, foreign or local. Finally, the macroeconomic variables are collected from the Statistical Data Warehouse of the European Central Bank (SDW), the Czech Statistical Office (CZSO) and the CNB's public database ARAD. ARAD contains time series of monetary indicators, aggregated financial markets data, balance of payments statistics and fiscal statistics. ARAD data is processed directly by the CNB, but also comes

\footnotetext{
${ }^{3}$ We consider solely loans and overdrafts granted by the bank, and exclude unauthorized debits and loans bought from other banks.
} 
from external sources such as the CZSO. The macrofinancial variables include overnight money market rates (CZEONIA and EONIA), GDP growth rates and consumer price indices (CPI) for the Czech and euro area economies as well as the exchange rate between the Czech koruna and the euro.

The Central Credit Register of the Czech National Bank contains monthly information on clients' loans, overdrafts, current account debit balances, guarantees, undrawn lending arrangements and standby credits. Our study focuses solely on the first three categories. The CCR data includes the loan identification number, NACE code ${ }^{4}$, type, purpose, currency and classification. In accordance with CNB amending Regulation No. 193/1998, Czech banks classify loans according to a five-tier scheme and assign each loan a "standard", "watch", "substandard", "doubtful" or "loss" grade. In the case of nonperforming loans, the dataset provides information on the loan's principal, interest, fees and days overdue. Moreover, the CCR records the loan amounts granted and remaining as well as the dates of loan origination, maturity and, if applicable, write-off.

The firm-related covariates are obtained from two sources: the CCR and the Magnus database maintained by CEKIA. The Magnus data is mostly available at a yearly frequency. CEKIA supplies business information about Czech companies and their financial statements, namely balance sheets and profit and loss accounts. The corporate characteristics cover the firm's identification number, NACE code ${ }^{5}$, legal form, ownership type, amount of registered capital, number of employees, turnover and state of operation. The Magnus dataset also carries information on the dates when the company was launched and, where applicable, ceased to operate. Additionally, it contains the firm's position among the top 100 Czech companies and its rating, if provided by the Czech Rating Agency. The accounting variables are numerous and include, among others, the value of assets (total, fixed, current and other), equity, liabilities (total, other), sales, costs, operating income and net and pre-tax profits.

\subsection{Data Description and Construction of Variables}

In the paper, we use several money market rates to represent the monetary conditions in which Czech banks operate. Given that in the Czech Republic most traditional banking business is done in local currency (Czech koruna), the koruna money market rates (such as the PRIBOR reference rates or the overnight CZEONIA index) are the relevant variables to which banks react. The central bank of the Czech Republic, the Czech National Bank (CNB), pursues an independent monetary policy within its inflation targeting regime and a floating exchange rate.

\footnotetext{
${ }^{4} \mathrm{NACE}$ is the European industry standard classification system (Statistical Classification of Economic Activities in the European Community).

${ }^{5}$ The same classification system as in the case of loans (the European industry standard classification system), although this time the code applies to the company's industry.
} 
The Czech banking market is not euroized - the share of foreign currency loans in total loans to households is virtually zero. This contrasts with the situation in many other Central and Eastern European countries, where FX loans to households are much more common. The main reason for the total dominance of local currency loans is the very low and sometimes even negative spread between koruna and FX interest rates, so that households have not had any incentive to demand FX loans in order to benefit from better interest rate conditions. In the non-financial corporations segment, FX loans exist, but only on a relatively minor scale (roughly $20 \%$ of loans to non-financial corporations are denominated in foreign currencies, mainly euro). This instrument is used mainly by exportoriented companies and commercial real estate developers for hedging purposes, as these two types of corporations have large revenues in euro.

Nevertheless, given the deep economic integration of the Czech Republic into the rest of the EU via foreign trade, the Czech business cycle is to a large extent synchronized with that of the Eurozone and especially Germany. Therefore, Czech monetary policy rates - and thus also money market rates, which follow monetary policy rates quite closely - co-move with ECB monetary policy rates. The relationship works via two channels - directly, i.e. via the exchange rate transmission channel (a decrease in ECB rates and thus euro area money market rates leads to appreciation of the Czech koruna vis-a-vis the euro, contributing to lower inflation pressures and thus lower CNB rates), and indirectly, via common movement of the Eurozone and Czech economies in the cycle.

A natural candidate for capturing the monetary conditions in the Czech Republic is CZEONIA. CZEONIA is a weighted average of overnight $(\mathrm{O} / \mathrm{N})$ rates on trades executed in a given day and, as such, it reflects real trading in the money market among Czech banks. Moreover, the $\mathrm{O} / \mathrm{N}$ segment is the most liquid part of money market trading $(\mathrm{CNB}, 2010)$. We could also employ the PRIBOR rate. However, PRIBOR rates are solely reference rates and do not reflect real trading. As discussed in the methodology section, in order to properly capture the effect of the monetary conditions on credit risk both on the date of loan origination and during the life of individual loans, we have to control for potential reverse causality and endogeneity of the monetary conditions represented by CZEONIA. CZEONIA, mirroring the official $2 W$ repo rate of the CNB, may itself strongly depend on the level of credit risk in the banking system, as the central bank would react to worsening economic conditions and an increase in bad loans in banks' portfolios by decreasing the official CNB repo rates. Furthermore, if we happen to ignore controls correlated with both the Czech monetary stance and Czech banks' risk-taking, our analysis would suffer from omitted variable inconsistency. Thus, we use EONIA as an instrument, or alternatively a proxy, for CZEONIA. The tests applied confirmed that EONIA is a valid instrument for CZEONIA, reflecting strong correlation between these two rates as discussed above. Therefore, throughout our analysis we rely upon the monthly average of euro area money market overnight rates to capture the existing monetary policy conditions in the Czech Republic. 
Apart from interest rates, each duration or probit model contains a set of macroeconomic variables to control for major economic developments in the Czech Republic. The set includes Czech inflation ${ }^{6}\left(C P I_{t}\right)$ and the spread ${ }^{7}$ between Czech and European Monetary Union 10-year maturity government bond yields $\left(\right.$ Country risk $_{t}$ ) dated at loan origination. We also add a time trend and time trend squared, which are functions of calendar time. In the duration models we also incorporate two GDP growth rates, one dated prior to loan origination and the other prior to loan default or maturity. The probit analysis, which lacks the dynamic loan-life perspective, contains solely the GDP growth rate prior to loan origination. GDP growth is the seasonally adjusted quarterly rate of change of gross domestic product in the Czech Republic.

Banks tend to differ in their lending strategies and thus also in their credit risk behaviour. In order to account for differences in credit risk profiles across banks, and for the reasons discussed in the methodology section, we introduce bank characteristics stemming from the CCR as well as the banks' financial statements reported to the CNB. We include bank size, bank type and risk appetite as well as the liquidity and own funds to total assets ratios. Typically, bank size is given as the logarithm of total assets. Bank type is a dummy variable equal to one if the loan is granted by a foreign-owned bank. Liquidity ratio ${ }_{t-1}$ and Own funds/total assets $t-1$ are, respectively, the bank's liquid assets over its total assets and its equity over total assets. The difference between the bank's and other banks' non-performing loan ratios, Bank $N P L_{b}-N P L_{t-1}$, measures the credit risk already on the books.

As discussed in the methodology section, in the absence of loan pricing data, we apply the second-best empirical strategy to separate the loan supply and demand effects by controlling for changes in the quality of borrowers and loan characteristics. As the borrower-related controls we employ the firm's turnover and employment categories as well as the firm's regional and industry dummies. In addition, we construct measures of the firm's age and its number of bank relations. The turnover and number of employees categories are obtained based on the classes recorded in the CCR. The regional and industry dummies are also derived from CCR data. Following Jiménez, Ongena, Peydró-Alcalde, and Saurina (2007) we proxy the firm's age by its age as a borrower, that is the time since the origination of the first loan taken by the firm. Bank relations $t_{-1}$ is the logarithm of the number of bank relationships of the borrower plus one measured prior to loan origination. By the same token, Bank debt $t_{t-1}$ is the logarithm of the borrower's total amount of bank debt augmented by one. We account for the changing pool of loans by controlling for their size, purpose, maturity and currency and the way they are collateralized. We calculate the loan size as the logarithm of the amount granted. The effect of loan maturity is captured by three dummy variables accounting for terms of up to three, six and twelve months. Dummy variables are also employed to allow for difference in

\footnotetext{
${ }^{6}$ Inflation is measured by monthly consumer price indices (CPI).

${ }^{7}$ Monthly averages.
} 
the riskiness of loans with collateral and granted ${ }^{8}$ in euros, dollars or pounds as opposed to other currencies. The CCR dataset contains ten possible variables accounting for the type of collateral and fifteen possible types. We coarsely classify each type based on its riskiness and pool those with a similar likelihood of default. As a result we obtain ten collateral dummy variables displayed together with their statistical characteristics in Table 1.

Table 1: Collateral Type: Data Descriptive Statistics

\begin{tabular}{l||c|cccc}
\hline \hline Variable & Unit & Mean & Std Dev & Max & Min \\
\hline No collateral & $0 \mid 1$ & 0.34 & 0.47 & 1.00 & 0.00 \\
Pledge on own real estate & $0 \mid 1$ & 0.15 & 0.36 & 1.00 & 0.00 \\
Pledge on third party's real estate & $0 \mid 1$ & 0.02 & 0.14 & 1.00 & 0.00 \\
Pledge on movable property without transfer & $0 \mid 1$ & 0.02 & 0.15 & 1.00 & 0.00 \\
Ensuring note & $0 \mid 1$ & 0.25 & 0.43 & 1.00 & 0.00 \\
Guarantee deposit & $0 \mid 1$ & 0.02 & 0.14 & 1.00 & 0.00 \\
Guarantee & $0 \mid 1$ & 0.05 & 0.21 & 1.00 & 0.00 \\
Pledged assets & $0 \mid 1$ & 0.07 & 0.26 & 1.00 & 0.00 \\
Blockage of premium & $0 \mid 1$ & 0.00 & 0.07 & 1.00 & 0.00 \\
Other collateral & $0 \mid 1$ & 0.05 & 0.22 & 1.00 & 0.00 \\
\hline \hline
\end{tabular}

While investigating banks' risk-taking behaviour in the Czech banking system, we also examine whether or not it depends on the type of bank lending strategy - focused or diversified. We measure the banks' loan portfolio diversification using the Hirschman-Herfindahl Index. The Hirschman-Herfindahl Index ( $H H I)$ is a commonly accepted measure of concentration, which we employ to measure each bank's relative credit exposure to a particular industry prior to new loan origination. The index is the sum of the squares of banks' relative credit exposures to each industry. The data suggest that on average, Czech banks moderately increased their loan portfolio diversification until mid-2008, while after that a very slight decline happened.

${ }^{8}$ Loan $_{\text {currency }}=1$ if the loan is granted in euros, dollars or pounds. 


\section{Results}

\subsection{Ex-ante Riskier Borrowers}

In this section we explore Czech banks' appetite for ex-ante riskier borrowers at times of monetary easing. In particular, we examine whether lower interest rates promote more lending to corporate clients with overdue loans prior to new loan origination. This question is addressed by estimating the probability that a new loan is granted to a borrower with a recent bad credit history. Those recently "bad" borrowers, or - more accurately - borrowers with overdue loans six months prior to new loan origination, are considered to be "ex-ante riskier". We estimate a probit model using the bank, firm, loan and macroeconomic variables described in the data section, and primarily focus on the impact of the interest rate present in the money market one month prior to loan origination. The estimation results are given in Table 2 .

The instrumental variable probit regression shows that expansive monetary policy encourages Czech banks to grant fewer loans to borrowers who exhibited a recent bad credit history prior to loan origination. This means that lower interest rates imply less credit risk incurred by Czech banks. Consequently, our data do not support hypothesis $H 1$ and contradict the findings of Ioannidou, Ongena, and Peydró-Alcalde (2007) and Jiménez, Ongena, Peydró-Alcalde, and Saurina (2008). However, the probit results of our study and the other two are not completely comparable due to differences in defining the dependent variables. In Ioannidou, Ongena, and Peydró-Alcalde (2007), bad credit history refers to borrower past default and not to non-performance. Prudential regulations prevent Czech banks from financing previously defaulted firms. Jiménez, Ongena, Peydró-Alcalde, and Saurina (2008) classifies a borrower as ex-ante riskier when it is overdue on another loan, as in our study, but contrary to us checks any time before the new loan is granted. As the CCR was launched in 2002 and our analysis spans to the year 2010, we consider solely the six-month period preceding new loan origination. ${ }^{9}$ The other coefficients are mostly as expected. Larger banks, ceteris paribus, are less prone to lend to firms with a recent bad credit history. By the same token, banks holding more liquid assets are likely to accept fewer risky borrowers. Moreover, banks with higher than average non-performing loan ratios are less inclined to tolerate additional risk and finance companies with overdue loans in the previous six months. Surprisingly, the estimation output suggests that less leveraged (more capitalized) banks are likely to grant loans to borrowers with a risky past, while more indebted borrowers are less likely to have a recent bad credit history. Table 3 presents the riskiness of industries obtained within the instrumental probit framework. We note that lower interest rates imply, ceteris paribus, a lower likelihood of default on loans granted to manufacturers and higher defaults on loans provided to

\footnotetext{
${ }^{9}$ We also experiment with one year prior to new loan origination and obtain the same positive dependence.
} 
construction companies. Finally, we observe recent default or bad history less frequently in the case of younger firms with fewer bank relationships.

\begin{tabular}{|c|c|c|}
\hline Variable & Coefficient & Std. Err. \\
\hline${\text { Interest } \text { rate }_{t-1}}$ & $0.152^{* * *}$ & 0.012 \\
\hline Bank size $_{t-1}$ & $-0.025^{* * *}$ & 0.005 \\
\hline Liquidity ratio $t-1$ & $-1.910^{* * *}$ & 0.036 \\
\hline Bank $\mathrm{NPL}_{b}-\mathrm{NPL}_{t-1}$ & $-0.721^{* * *}$ & 0.070 \\
\hline Own funds/total assets $t-1$ & $0.190^{* *}$ & 0.083 \\
\hline Bank type $_{t-1}$ & $0.139^{* * *}$ & 0.015 \\
\hline $\ln (2+\text { age as borrower })_{t-1}$ & $0.166^{* * *}$ & 0.004 \\
\hline Bank relations $_{t-1}$ & $0.757^{* * *}$ & 0.015 \\
\hline Bank debt $t-1$ & $-0.016^{* * *}$ & 0.001 \\
\hline Loan $\operatorname{size}_{t}$ & $0.020^{* * *}$ & 0.002 \\
\hline Loan currencyt & $0.235^{* * *}$ & 0.015 \\
\hline Maturity $0-3$ months $_{t}$ & $0.345^{* * *}$ & 0.017 \\
\hline Maturity $3-6$ months $_{t}$ & $0.251^{* * *}$ & 0.018 \\
\hline Maturity $6-12$ months $_{t}$ & $0.252^{* * *}$ & 0.012 \\
\hline Loan purpose $t$ & $-0.085^{* * *}$ & 0.008 \\
\hline $\mathrm{GDPCR}_{t-1}$ & $-0.018^{* * *}$ & 0.002 \\
\hline $\mathrm{CPI}_{t}$ & $-0.009^{* *}$ & 0.004 \\
\hline Country risk $t$ & $0.048^{* * *}$ & 0.015 \\
\hline Time trend & $0.015^{* * *}$ & 0.001 \\
\hline Time trend sq. & $0.000^{* * *}$ & 0.000 \\
\hline Intercept & $-1.632^{* * *}$ & 0.072 \\
\hline Collateral dummies & \multicolumn{2}{|c|}{ yes } \\
\hline Firm turnover categories & \multicolumn{2}{|c|}{ yes } \\
\hline Firm employment categories & \multicolumn{2}{|c|}{ yes } \\
\hline Firm regional dummies & \multicolumn{2}{|c|}{ yes } \\
\hline Firm industry dummies & \multicolumn{2}{|c|}{ yes } \\
\hline $\mathrm{N}$ & \multicolumn{2}{|c|}{205,270} \\
\hline$\chi_{(49)}^{2}$ & \multicolumn{2}{|c|}{$21,841.344$} \\
\hline Wald $\chi_{(1)}^{2}$ & \multicolumn{2}{|c|}{410.84} \\
\hline
\end{tabular}

The endogeneity problem is detected both by the Wald statistic, reported in Table 2, and the tests robust to weak instruments. The test outcome obtained in the presence of potentially weak instruments, an approach due to Finlay and Magnusson (2009), is provided in Table A3. We rely on IV probit estimates rather than on the coefficients of the regular probit regression, but the two approaches yield similar results with respect to the monetary policy impact. To be precise, we refer to the probit model as the one estimated on the loan-level clusters. We also perform probit analysis on clusters of borrowers. Since the outcome corrected for firm-level clustering remains almost unaltered, we refrain from reporting it. The probit estimates corrected for loan clustering and the corresponding robust standard errors are reported in Table A4 in Appendix A. One final remark concerning endogeneity is that its presence strengthens the main points and concerns underlying our previous discussion of the potential reverse causality issue.

We fit the probit model to assess the influence of the monetary policy stance 
Table 3: Instrumental Probit Estimation Results for Industries

\begin{tabular}{lcc}
\hline \multicolumn{1}{c}{ Variable } & Coefficient & Std. Err. \\
\hline Manufacturing & $0.120^{* * *}$ & 0.014 \\
Other & $-0.091^{* * *}$ & 0.018 \\
Repair \& related & $-0.586^{* * *}$ & 0.082 \\
Electricity, gas \& heat & 0.079 & 0.057 \\
Water distribution \& related & $0.137^{* * *}$ & 0.028 \\
Construction & $-1.185^{* * *}$ & 0.117 \\
Motor vehicle trade & -0.022 & 0.018 \\
Transport & $0.038^{* * *}$ & 0.015 \\
Accommodation & $0.073^{* * *}$ & 0.025 \\
Broadcasting & $-0.166^{* * *}$ & 0.025 \\
Information activities & $0.115^{* * *}$ & 0.034 \\
Financial intermediation & 0.044 & 0.044 \\
R\&D, advertising \& market research & $-0.155^{* * *}$ & 0.030 \\
Scientific \& technical activities & $-0.068^{* * *}$ & 0.019 \\
Security \& investigation & $-0.578^{* * *}$ & 0.098 \\
Education & $-0.222^{* * *}$ & 0.042 \\
Artistic \& entertainment activities & $-0.579^{* * *}$ & 0.074 \\
Gambling & $0.385^{* * *}$ & 0.042 \\
Sport \& recreation & $-1.416^{* * *}$ & 0.172 \\
\hline \hline N & \multicolumn{2}{c}{204,757} \\
$\chi_{(65)}^{2}$ & $22,304.536$ \\
\hline
\end{tabular}

on banks' willingness to accept ex-ante riskier borrowers. If Czech banks were more prone to grant loans to ex-ante riskier firms at times of monetary expansion, we could claim that banks believed economic fundamentals were strong enough to reduce the default probability. One reason for that could have been higher net worth of borrowers in periods of lower interest rates. However, our data do not confirm that. One possible explanation of the link between low interest rates and lower probability of granting loans to borrowers with a riskier past might be the specific time period for which the analysis is done, which was marked by several structural changes. As banks were privatized before 2002, the banking sector experienced no state interventions and was relatively competitive in the period 2002-2010. Nevertheless, the rises and falls of money market rates (mirroring the CNB repo rate) between 2002 and 2009 happened under different conditions. There were two pronounced sub-periods of monetary policy expansion (2002-2004 and 2007-2009) and one pronounced sub-period of monetary policy tightening (2005-2007). In the first expansionary period of 2002-2004, the major domestic banks had just been cleared of nonperforming assets dating from the 1990s, as a part of a balance sheet consolidation process before privatization, and started to refocus their business on household loans. In this sub-period, referred to in the literature as a "credit crunch" in the corporate segment (Geršl and Hlaváček, 2007), corporate loans were declining and banks were not keen on providing new loans to corporations with a bad credit history despite the monetary expansion, effectively decreasing their risk-taking. The second monetary expansion, in 2007-2009, was a reaction to the global economic crisis and the economic recession in the euro area, again a period 
when banks were not keen on financing risky borrowers. On the contrary, anecdotal evidence shows that in this period, banks decreased their risk-taking, got rid of risky borrowers and maintained their loan relationships with rather less risky ones. In the period of monetary tightening, 2005-2007, which was itself a reaction to accumulating inflation pressures due to the strong economic and credit boom in those years, the banks strengthened their risk-taking owing to both competitive pressures and overall optimism in the economy, relaxed their lending standards and fuelled the credit boom even further, despite increases in money market rates. These structural factors are likely to have produced the puzzling positive relation between interest rate levels and banks' appetite for risk.

We conducted several robustness checks on the probit estimations. We test our hypotheses on models developed according to the guidelines of Hosmer \& Lemeshow (1999, pp. 158-180) and Hosmer \& Lemeshow (2000, pp. 92-116) for the probit regressions. Both suggest an approach to building a model with covariates chosen optimally. Generally, our choice of covariates is grounded in economic reasoning, supported, to some extent, by the findings of the previous studies, such as Ioannidou, Ongena, and Peydró-Alcalde (2007) and Jiménez, Ongena, Peydró-Alcalde, and Saurina (2008). When constructing the specifications for the robustness checks, we greatly emphasize another important variable selection criterion, namely statistical significance. We employ the fractional polynomials methodology as a tool to validate the significance of the variables. The methodology of fractional polynomials is presented in Appendix B. When necessary, we also use fractional polynomials to suggest transformations of the continuous variables. All the steps involved in building the statistically desirable probit models for our data are also discussed in Appendix B. There are cases where the methodology suggested the inclusion of additional predictors, some transformation of continuous covariates or different grouping of selected categorical variables. Therefore, Table $B 1$ contains the definitions of the optimally chosen covariates which differ from the ones employed in the main part of our analysis. The reasoning provided above also applies to the survival analysis (see next section). The descriptive statistics of the alternative predictors are summarized in Tables $B 2-B 4$.

Similarly to our regular probit analysis, the estimates obtained for the robust probit suggest that a relaxed monetary policy encourages Czech banks to finance fewer borrowers with a recent bad credit history. Therefore, the model with optimally selected covariates also does not support hypothesis $H 1$, which says that lower interest rates lead to more lending to borrowers with a riskier past. As in the case of our main probit regressions, we reject the null hypothesis of no endogeneity and rely on IV probit estimates. Still, the two approaches produce comparable outcomes, which for the probit model with observations clustered on the loan level are displayed in Tables B5-B9 in Appendix B. Additionally, we perform the analysis on borrower clusters and obtain almost unaltered coefficients. 
Table 4: Estimation Results for the Robust Instrumental Probit

\begin{tabular}{|c|c|c|}
\hline Variable & Coefficient & Std. Err. \\
\hline${\text { Interest } \text { rate }_{t-1}}$ & $0.471^{* * *}$ & 0.020 \\
\hline Bank size $_{t-1}$ & $-0.028^{* * *}$ & 0.007 \\
\hline Liquidity ratio $t-1$ & $-1.123^{* * *}$ & 0.058 \\
\hline Bank NPL $L_{b}-\mathrm{NPL}_{t-1}$ & $-1.402^{* * *}$ & 0.173 \\
\hline Own funds/total assets $_{t-1}$ & $-0.466^{* * *}$ & 0.152 \\
\hline Deposit ratio $_{t-1}$ & $1.228^{* * *}$ & 0.069 \\
\hline Bank unit $_{t-1}$ & $-0.224^{* * *}$ & 0.014 \\
\hline $\ln (2+\text { age as borrower })_{t-1}$ & $0.411^{* * *}$ & 0.006 \\
\hline Bank relations $_{t-1}$ & $1.412^{* * *}$ & 0.016 \\
\hline Loan currency $t$ & $-0.159^{* * *}$ & 0.022 \\
\hline Maturity $2-3.5$ years $t$ & $-0.074^{* * *}$ & 0.015 \\
\hline Maturity $4-8$ years $_{t}$ & $-0.311^{* * *}$ & 0.014 \\
\hline Maturity 5.5 years $_{t}$ & $0.342^{* * *}$ & 0.032 \\
\hline Maturity $8.5-10$ years $_{t}$ & $-0.181^{* * *}$ & 0.026 \\
\hline $\mathrm{GDPCR}_{t-1}$ & $0.021^{* * *}$ & 0.003 \\
\hline $\mathrm{CPI}_{t}$ & $-0.138^{* * *}$ & 0.006 \\
\hline Country risk $t$ & $0.195^{* * *}$ & 0.025 \\
\hline Time trend & $0.015^{* * *}$ & 0.001 \\
\hline Time trend sq. & $0.000^{* * *}$ & 0.000 \\
\hline Intercept & $-4.067^{* * *}$ & 0.102 \\
\hline Loan collateral: $1^{\text {st }}-3^{\text {rd }}$ & \multicolumn{2}{|c|}{ yes } \\
\hline Loan purpose: [1]-[5] & \multicolumn{2}{|c|}{ yes } \\
\hline Firm turnover categories & \multicolumn{2}{|c|}{ yes } \\
\hline Firm employment categories & \multicolumn{2}{|c|}{ yes } \\
\hline Firm regional dummies & \multicolumn{2}{|c|}{ yes } \\
\hline Firm industry dummies & \multicolumn{2}{|c|}{ yes } \\
\hline $\mathrm{N}$ & \multicolumn{2}{|c|}{207,352} \\
\hline$\chi_{(67)}^{2}$ & \multicolumn{2}{|c|}{$24,849.675$} \\
\hline Wald $\chi_{(67)}^{2}$ & \multicolumn{2}{|c|}{286.23} \\
\hline
\end{tabular}

Following the optimal variable selection strategy for the probit regressions results in the inclusion of an additional bank characteristic (Deposit ratio D $_{t-1}$ ), a different bank type measure (Bank unit $t_{t-1}$ ) and an altered grouping of loan maturity, purpose and collateral. Bank unit is a dummy variable taking the value of one if the loan is granted by a branch in the Czech Republic (as opposed to a headquarters in the Czech Republic or a branch abroad). Additionally, Bank debt $t_{t-1}$ and loan size are excluded from the alternative probit specification. Thus, we solely compare the other estimated parameters for bank and firm covariates. We observe a reverse sign of the bank capital measure. Contrary to our main analysis findings, here banks holding more own funds are likely to accept fewer risky borrowers. The other coefficients in the robust and regular probit analysis are alike. Larger and more liquid banks are less prone to lend to firms with a recent bad credit history. Moreover, banks with higher than average non-performing loan ratios are less likely to tolerate additional risk and finance companies that were late with loan payments in the previous six months. Finally, we observe recent default or bad history less frequently in the case of younger firms with fewer bank relationships. 


\subsection{Dynamic Riskiness of Loans}

Duration models of loan default consider not only the default itself, but also its timing. As in the probit regression, we still account for observed and unobserved loan quality by origination date. However, in addition to that, survival analysis enables us to capture the changing conditions over the loan life. Thus, we may investigate bank risk-taking in a broader, dynamic, context. This richer approach also allows for a richer set of covariates. Duration analysis enables us to examine the impact of the monetary policy stance on the riskiness of new loans as well as its effect on the existing loan portfolio. Therefore, our hazard rate models comprise not only the interest rate measured prior to loan origination, but also the interest rate prior to loan default or maturity. The latter allows us to test how monetary policy affects the performance of loans already on the books. We also incorporate two GDP growth rates, one dated prior to loan origination and the other prior to loan default or maturity.

We fit four duration models and contrast their outcomes. The rationale for each specification is laid out in the empirical strategy section. The survival models differ in line with the shifting focus of our analysis. Nevertheless, each formulation contains the core covariates, namely a set of macroeconomic variables to control for major economic developments in the Czech Republic. The first two models, Model I and Model II, control for diverse lending strategies across banks. The former is the estimated shared frailty survival model, with frailties common to loans of the same bank. The latter analyses a duration model with bank characteristics incorporated in an explicit manner. Model III accounts for the changes over time in the pool of borrowers and loans, and includes the firm and loan covariates. Model IV further enriches our analysis with the loan portfolio concentration measure $(H H I)$.

The coefficient on the short interest rate preceding loan origination is negative and significant in all the estimated formulations. The models with bank unobserved heterogeneity (Model I) and loan portfolio diversification (Model IV) yield coefficients significant solely at the 10 per cent level. The two other models render even more significant negative results. Therefore, all cases indicate that at times of lower interest rates banks tend to grant loans with higher hazard rates. In other words, a more relaxed monetary conditions policy encourages banks to take on more credit risk. This finding gives support to hypothesis $H 2$ and corroborates the outcomes of Ioannidou, Ongena, and Peydró-Alcalde (2007) and Jiménez, Ongena, Peydró-Alcalde, and Saurina (2008).

All four formulations produce highly significant and positive estimated coefficients on the interest rate prevailing during the loan life. The positive dependence in all four cases implies that the higher the interest rate prior to loan maturity, the greater the probability of loan default per time period. This result is as expected and can be attributed to lower refinancing costs or a reduced loan repayment burden at times of low interest rates. Thus, relaxed monetary conditions give rise to fewer loan defaults or lower riskiness of the outstanding 
portfolio.

The results for the GDP growth rate offer limited scope for interpretation. Out of the two rates, solely the GDP growth rate during the loan life proves to be statistically significant. Moreover, it is significant only when borrower characteristics are accounted for. We obtain a significant and negative coefficient on the GDP growth rate during the loan life for the specification with bank, loan and borrower covariates without and with the measure of loan portfolio diversification. The direction of the effect of GDP on the riskiness of the outstanding portfolio is as expected. At times of higher economic growth, loan defaults are less frequent. The parameters for inflation remain positive and highly significant for all four models. They indicate that higher inflation at origination increases the loan hazard rate. Finally, the negative and highly significant estimated coefficients on the time trend indicate an overall decrease in new credit volume observed over (calendar) time in the Czech banking sector. Indeed, since 2002 Czech banks have substantially changed their lending strategies and credit risk assessment. This observed general improvement is revealed on top of the effects captured by bank characteristics and the change in the pool of loans and borrowers.

Next, we focus on the results for bank characteristics. The sole bank covariates that prove to be statistically significant in all three model specifications ${ }^{10}$ are bank liquidity and type. We find that more liquid banks, ceteris paribus, are likely to grant loans with lower hazard rates. The inverse influence of the bank's liquidity on its loan hazard rate supports hypothesis $H 4$ and suggests that banks accumulating liquid assets tend to grant less risky loans, thus confirming one of the implications of Diamond and Rajan (2006). The bank size effect proves to be positive in the specification with bank covariates. Such an outcome indicates that larger banks are willing to accept more credit risk. One might argue that in a banking sector dominated by few banks, as in the Czech Republic, the positive bank size could be attributable to a "too big to fail" effect. In doing so, we would employ the same line of argument as Boyd and Runkle (1993) and Ioannidou, Ongena, and Peydró-Alcalde (2007), who obtained similarly puzzling estimates for their data. In our study, Model II is the only case where the size effect is significant. Finally, we obtain that foreign banks tend to extend more hazardous loans. The impact of all other bank characteristics is statistically insignificant. Therefore, we find no support for hypothesis $H 3$, which relates bank capital and credit risk appetite.

In the Czech Republic, the association between high liquidity and low risk appetite (low hazard rates) may be explained by a preference of most large banks to attract and keep depositors. Domestic banks apply a very conservative banking model, hardly engage in risky investments and focus on collecting deposits and granting loans. Moreover, compared to their European counterparts, Czech

\footnotetext{
${ }^{10}$ In Model I differences between banks are captured by the "frailty effect". Given the standard error of $\theta$ and the likelihood-ratio test statistic $\left(\bar{\chi}_{(01)}^{2}=47.25\right)$, we find a significant frailty effect, meaning that the correlation across loans grouped by banks cannot be ignored.
} 
banks are very prudent in their lending activities and prefer to maintain low credit risk profiles. At the same time, they prefer to hold large liquidity buffers, mainly for two reasons: first, when relying on a large pool of (mainly sight) deposits, the banks need liquid assets to be able to saturate potential demand for liquidity should deposit withdrawals increase in stress times; second, a large liquidity buffer is an important signal - together with low credit risk indicators - to existing and potential depositors. Moreover, given their conservative banking model and overhang of deposits, most domestic banks invest in Czech government bonds, which constitute an important part of their liquid assets (CNB, 2010/2011).

Furthermore, we examine the estimated impact of loan and borrower covariates. Not surprisingly, we obtain that hazardous borrowers are more likely to default in the future. To measure the firm's riskiness we look for previous overdue loans in its recent credit history. As in the probit analysis, younger firms are safer. In other words, loans to younger firms tend to survive longer. Table 6 presents the hazard rates for firm industries. Interestingly, all significant industry effects are solely positive. Such results indicate that lower interest rates imply, ceteris paribus, a lower likelihood of default or no significant effect of loans granted to all but agricultural producers. By introducing credit size, purpose, currency and maturity we wish to control for modifications in the loan pool over the time span of our study. We find that modest-sized loans tend to be more risky. The estimated effect of loan purpose, captured by a dummy for overdrafts, suggests that overdrafts and current account debits exhibit a lower hazard rate. Additionally, loans granted in euros, dollars or pounds are more hazardous than the others, which are mostly granted in Czech koruna. The influence of each loan maturity dummy is highly significant and positive. All the same, the magnitude of the estimated maturity parameters decreases with the loan maturity. In other words, the shorter the loan term, the greater the probability of default.

Adding the diversification measure of banks' corporate loan portfolio only slightly modifies the magnitude of the effect of bank, firm and loan covariates on the hazard rate. In all but one case we note no change of sign or significance level. The sole exception is the bank capital coefficient, which remains insignificant, but changes sign. Finally, we obtain that in the analysed period the type of lending strategy, diversified or focal, has no explanatory power for Czech banks' risk appetite. We present solely the results for the Herfindahl-Hirschman index. However, we find that using neither the Gini coefficient nor the Shannon entropy as a concentration measure speaks in support of hypothesis $H 5$.

As to the robustness checks, we used the same approach as in the probit analysis. We proceed with modelling the time to loan default, our other measure of risk-taking. We consider the statistically robust survival model with bank characteristics. The choice of bank-level controls used here is described in Appendix B. In the duration model we include bank size, risk appetite and profitability, bank unit, and the ratios of liquidity and own funds to total assets. Bank size 
Table 5: Estimation Results for Duration Models

\begin{tabular}{|c|c|c|c|c|}
\hline Variable & Model I & Model II & Model III & Model IV \\
\hline Interest rate $_{t-1}$ & $\begin{array}{c}-0.214^{*} \\
(0.129)\end{array}$ & $\begin{array}{c}-0.312^{* *} \\
(0.131)\end{array}$ & $\begin{array}{c}-0.298^{* *} \\
(0.149)\end{array}$ & $\begin{array}{l}-0.289^{*} \\
(0.151)\end{array}$ \\
\hline Interest rate $_{T-t-1}$ & $\begin{array}{c}0.279^{* * *} \\
(0.069)\end{array}$ & $\begin{array}{c}0.296^{* * *} \\
(0.066)\end{array}$ & $\begin{array}{c}0.278^{* * *} \\
(0.077)\end{array}$ & $\begin{array}{c}0.282^{* * *} \\
(0.077)\end{array}$ \\
\hline $\mathrm{GDPCR}_{t-1}$ & $\begin{array}{l}-0.018 \\
(0.037)\end{array}$ & $\begin{array}{c}0.006 \\
(0.038)\end{array}$ & $\begin{array}{c}-0.018 \\
(0.042)\end{array}$ & $\begin{array}{l}-0.013 \\
(0.042)\end{array}$ \\
\hline $\operatorname{GDPCR}_{T-t-1}$ & $\begin{array}{l}-0.019 \\
(0.028)\end{array}$ & $\begin{array}{l}-0.024 \\
(0.027)\end{array}$ & $\begin{array}{c}-0.066^{* *} \\
(0.032)\end{array}$ & $\begin{array}{c}-0.067^{* *} \\
(0.032)\end{array}$ \\
\hline Bank size $_{t-1}$ & & $\begin{array}{c}0.181^{* *} \\
(0.085)\end{array}$ & $\begin{array}{c}0.155 \\
(0.105)\end{array}$ & $\begin{array}{c}0.056 \\
(0.142)\end{array}$ \\
\hline Liquidity ratio $_{t-1}$ & & $\begin{array}{c}-3.083^{* * *} \\
(0.676)\end{array}$ & $\begin{array}{c}-3.437^{* * *} \\
(0.836)\end{array}$ & $\begin{array}{c}-3.758^{* * *} \\
(0.900)\end{array}$ \\
\hline Own funds/total assets t $_{t-1}$ & & $\begin{array}{l}-1.942 \\
(1.494)\end{array}$ & $\begin{array}{c}0.037 \\
(2.074)\end{array}$ & $\begin{array}{l}-0.061 \\
(2.119)\end{array}$ \\
\hline Bank $\mathrm{NPL}_{b}-\mathrm{NPL}_{t-1}$ & & $\begin{array}{c}0.048 \\
(0.429)\end{array}$ & $\begin{array}{l}-0.624 \\
(2.100)\end{array}$ & $\begin{array}{l}-1.616 \\
(2.786)\end{array}$ \\
\hline Bank type $_{t-1}$ & & $\begin{array}{l}0.470^{*} \\
(0.282)\end{array}$ & $\begin{array}{c}0.840^{* * *} \\
(0.312)\end{array}$ & $\begin{array}{c}0.831^{* * *} \\
(0.316)\end{array}$ \\
\hline $\ln (2+\text { age as borrower })_{t-1}$ & & & $\begin{array}{c}0.241^{* * *} \\
(0.085)\end{array}$ & $\begin{array}{c}0.249^{* * *} \\
(0.086)\end{array}$ \\
\hline Bad history $_{t-1}$ & & & $\begin{array}{c}1.129^{* * *} \\
(0.151)\end{array}$ & $\begin{array}{c}1.129^{* * *} \\
(0.151)\end{array}$ \\
\hline Bank relations $_{t-1}$ & & & $\begin{array}{l}-0.151 \\
(0.227)\end{array}$ & $\begin{array}{l}-0.170 \\
(0.228)\end{array}$ \\
\hline Loan $\operatorname{size}_{t}$ & & & $\begin{array}{c}-0.202^{* * *} \\
(0.021)\end{array}$ & $\begin{array}{c}-0.205^{* * *} \\
(0.021)\end{array}$ \\
\hline Loan $_{\text {currency }}$ & & & $\begin{array}{c}0.997^{* * *} \\
(0.228)\end{array}$ & $\begin{array}{c}0.989^{* * *} \\
(0.229)\end{array}$ \\
\hline Maturity $0-3$ months $_{t}$ & & & $\begin{array}{c}1.889^{* * *} \\
(0.443)\end{array}$ & $\begin{array}{c}1.915^{* * *} \\
(0.454)\end{array}$ \\
\hline Maturity $3-6$ months $_{t}$ & & & $\begin{array}{c}1.132^{* * *} \\
(0.411)\end{array}$ & $\begin{array}{c}1.134^{* * *} \\
(0.413)\end{array}$ \\
\hline Maturity $6-12$ months $_{t}$ & & & $\begin{array}{c}0.729^{* * *} \\
(0.232)\end{array}$ & $\begin{array}{c}0.710^{* * *} \\
(0.230)\end{array}$ \\
\hline Loan purpose $e_{t}$ & & & $\begin{array}{l}-0.553^{* * *} \\
(0.153)\end{array}$ & $\begin{array}{c}-0.557^{* * *} \\
(0.153)\end{array}$ \\
\hline $\mathrm{HHI}_{t-1}$ & & & & $\begin{array}{c}0.085 \\
(0.076)\end{array}$ \\
\hline $\mathrm{CPI}_{t}$ & $\begin{array}{c}0.215^{* * *} \\
(0.056)\end{array}$ & $\begin{array}{c}0.210^{* * *} \\
(0.056)\end{array}$ & $\begin{array}{c}0.194^{* * *} \\
(0.064)\end{array}$ & $\begin{array}{c}0.191^{* * *} \\
(0.064)\end{array}$ \\
\hline Country risk $_{t}$ & $\begin{array}{l}-0.410 \\
(0.290)\end{array}$ & $\begin{array}{c}-0.429 \\
(0.297)\end{array}$ & $\begin{array}{l}-0.563 \\
(0.343)\end{array}$ & $\begin{array}{l}-0.542 \\
(0.344)\end{array}$ \\
\hline Time trend & $\begin{array}{c}-0.097^{* * *} \\
(0.020)\end{array}$ & $\begin{array}{c}-0.098^{* * *} \\
(0.020)\end{array}$ & $\begin{array}{c}-0.095^{* * *} \\
(0.020)\end{array}$ & $\begin{array}{c}-0.095^{* * *} \\
(0.020)\end{array}$ \\
\hline Time trend sq. & $\begin{array}{c}0.001^{* * *} \\
(0.000)\end{array}$ & $\begin{array}{c}0.001^{* * *} \\
(0.000)\end{array}$ & $\begin{array}{c}0.001^{* * *} \\
(0.000)\end{array}$ & $\begin{array}{c}0.001^{* * *} \\
(0.000)\end{array}$ \\
\hline Collateral dummies & no & no & yes & yes \\
\hline Firm regional/industry dummies & no & no & yes & yes \\
\hline $\begin{array}{l}\mathrm{N} \\
\text { Log-likelihood } \\
\chi^{2}\end{array}$ & $\begin{array}{c}154,372 \\
-2,092.978 \\
108.63(8)\end{array}$ & $\begin{array}{c}154,368 \\
-2,103.071 \\
169.781(13)\end{array}$ & $\begin{array}{c}152,316 \\
-1,564.971 \\
563.224(40)\end{array}$ & $\begin{array}{c}152,316 \\
-1,564.218 \\
570.244(40)\end{array}$ \\
\hline
\end{tabular}

and the liquidity and leverage ratios are defined as in the regular survival analysis. The bank unit is designed as in the robust probit model and equals one if the loan is granted by a bank branch in the Czech Republic. As a measure 
Table 6: Estimation Results for Industries

\begin{tabular}{lcc}
\hline \hline \multicolumn{1}{c}{ Variable } & Coefficient & Robust Std. Err. \\
\hline Manufacturing & $1.539^{* *}$ & 0.719 \\
Other & $1.630^{* *}$ & 0.735 \\
Repair \& related & -41.827 & 0.000 \\
Electricity, gas \& heat & -43.143 & 0.000 \\
Water distribution \& related & $2.323^{* * *}$ & 0.779 \\
Construction & -41.215 & 0.000 \\
Motor vehicle trade & $1.262^{*}$ & 0.758 \\
Transport & $1.551^{* *}$ & 0.714 \\
Accommodation & $1.952^{* *}$ & 0.780 \\
Broadcasting & $1.956^{* *}$ & 0.775 \\
Information activities & 0.274 & 1.246 \\
Financial intermediation & -42.773 & 0.000 \\
R\&D, advertising \& market research & 0.606 & 0.916 \\
Scientific \& technical activities & 1.191 & 0.760 \\
Security \& investigation & $2.404^{* *}$ & 1.226 \\
Education & -43.602 & 0.000 \\
Artistic \& entertainment activities & -42.248 & 0.000 \\
Gambling & -42.981 & 0.000 \\
Sport \& recreation & -42.560 & 0.000 \\
\hline \hline N & \multicolumn{2}{c}{152,316} \\
Log-likelihood & $-1,552.528$ \\
$\chi_{(48)}^{2}$ & 594.003 \\
\hline
\end{tabular}

of the credit risk already on the books the fractional polynomials method suggested the inverse of the capital adequacy ratio $\left(C A R^{-1}{ }_{t-1}\right)$. Finally, we add to the model bank profits scaled down by millions of Czech korunas. We also use another measure of bank profitability, namely the return on equity $(R O E)$. Since the outcome with $R O E$ instead of scaled profits leaves the main results almost unaltered, we refrain from reporting it here. The estimation output is displayed in Table 7 .

Consistently with our core analysis, the coefficient on the interest rate prior to loan origination is negative and significant. This negative relationship indicates that an expansionary monetary policy encourages more credit risk-taking among banks. Moreover, the alternative specification with bank characteristics produces a positive and highly significant coefficient on the interest rate during the loan life. This positive dependence indicates that a higher interest rate prior to loan maturity raises the probability of loan default per time period and confirms our previous results. Thus, once again we find evidence to support hypothesis $H 2$.

As previously, higher inflation at origination tends to augment the loan hazard rate. In addition, the optimally derived bank-level specification confirms that banks with higher liquidity ratios are likely to grant loans with lower hazard rates. Not surprisingly, emphasizing statistical significance in variable selection produces a model with numerous significant characteristics. Therefore, in contrast to our main model with bank characteristics, here the impact of all bank 
Table 7: Estimation Results for the Robust Model with Bank Characteristics

\begin{tabular}{|c|c|c|}
\hline Variable & Coefficient & Robust Std. Err. \\
\hline Interest rate $_{t-1}$ & $-0.463^{* * *}$ & 0.141 \\
\hline Interest rate $_{T-t-1}$ & $0.290^{* * *}$ & 0.068 \\
\hline $\mathrm{GDPCR}_{t-1}$ & $0.074^{*}$ & 0.043 \\
\hline $\mathrm{GDPCR}_{T-t-1}$ & -0.021 & 0.027 \\
\hline Bank size $_{t-1}$ & $0.347^{* * *}$ & 0.105 \\
\hline 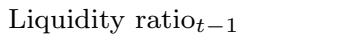 & $-3.559^{* * *}$ & 0.913 \\
\hline Own funds/total assets $t-1$ & $-11.994^{* * *}$ & 2.721 \\
\hline $\mathrm{CAR}^{-1} t-1$ & $-23.354^{* * *}$ & 5.471 \\
\hline Bank unit $_{t-1}$ & $-0.523^{* * *}$ & 0.162 \\
\hline Bank profit $_{t-1}$ & $-0.406^{* * *}$ & 0.076 \\
\hline $\mathrm{CPI}_{t}$ & $0.247^{* * *}$ & 0.061 \\
\hline Country risk $_{t}$ & $-0.540^{*}$ & 0.307 \\
\hline Time trend & $-0.092^{* * *}$ & 0.021 \\
\hline Time trend sq. & $0.001^{* * *}$ & 0.000 \\
\hline $\mathrm{N}$ & \multicolumn{2}{|r|}{136,680} \\
\hline Log-likelihood & \multicolumn{2}{|r|}{$-1,974.24$} \\
\hline$\chi_{(14)}^{2}$ & \multicolumn{2}{|r|}{210.815} \\
\hline
\end{tabular}

characteristics matters. More capitalized and profitable banks are likely to grant loans with lower hazard rates. The negative coefficient on own funds to total assets corroborates the theoretical findings of Keeley (1990), where banks with more capital exhibit a lower default risk. The negative coefficient on the inverse of the capital adequacy ratio suggests that banks persist in their hazardous lending.

Finally, we compare the two survival models with bank, loan and borrower characteristics. The estimation output for the survival model with robust borrower and loan covariates is provided in Table 8. Consistently with our core analysis, we observe that adding the firm and loan variables does not alter our key findings. A lower interest rate prior to loan origination increases the hazard rate of new loans. Once again, we find evidence in support of hypothesis $H 2$, which relates increases in bank riskiness to expansionary monetary conditions. At the same time, a lower short rate during the loan life decreases non-payment of outstanding loans. Contrary to the main model, the robust specification also produces a significant and negative coefficient on the GDP growth rate during the loan life. Therefore, the robust model suggests that more dynamic economic growth reduces the riskiness of the outstanding loan portfolio. The parameter for inflation remains positive and highly significant, which indicates that higher inflation at origination increases the loan hazard rate.

The bank, firm and loan covariates employed in the optimally built survival model are defined as in the corresponding main specification. However, the core survival analysis contains more bank, loan and borrower characteristics. Implementing the optimal variable selection strategy results in the exclusion of bank type, loan currency and the measure of bank relations maintained by the borrowers prior to new loan origination. In addition, the fractional polynomials 
Table 8: Estimation Results for the Robust Model with Bank, Loan and Borrower Characteristics

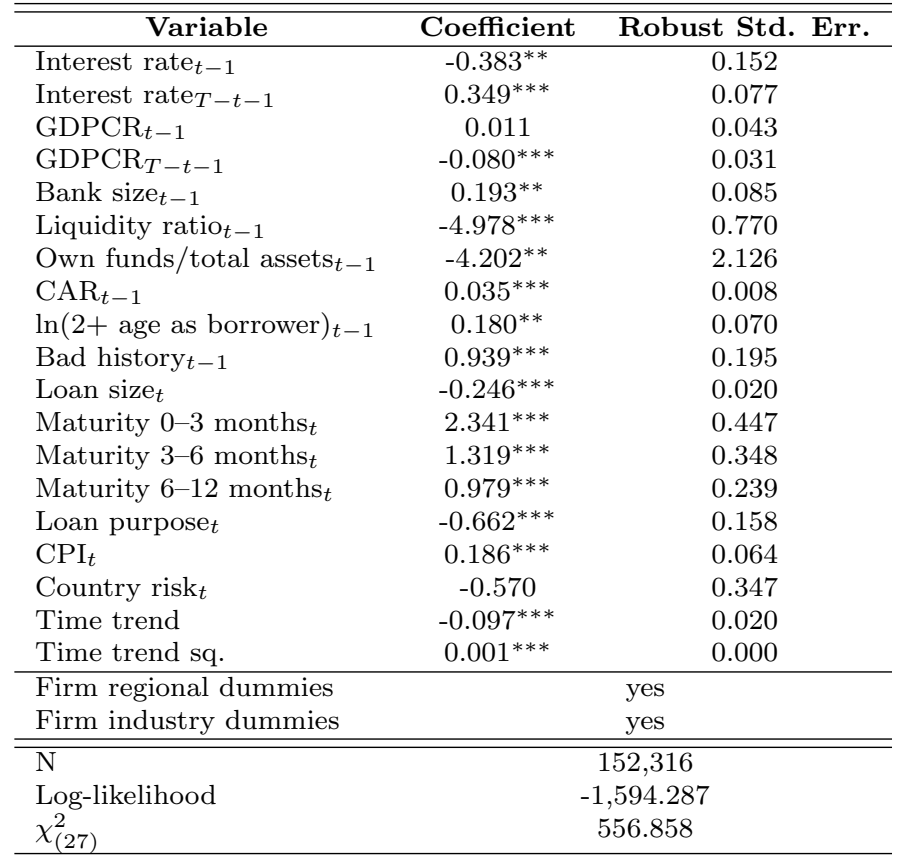

method suggested capturing the credit risk already on the books by the capital adequacy ratio $\left(C A R_{t-1}\right)$ instead of the non-performing loan ratio (Bank NPL $\left.b-N P L_{t-1}\right)$.

All characteristics included in both the main and robust model yield similar results. As in the core part of our survival study, more modest loans tend to be more risky. In both regression outputs, overdrafts have a lower hazard rate in the robust model than in the main model. Moreover, we obtain the same effect of loan maturity as in the main model, namely each coefficient on the maturity dummy is highly significant and positive. In addition, we observe that the shorter the loan term, the greater the probability of default. 


\section{Conclusions}

This paper contributes to the debate on the impact of monetary conditions on banks' appetite for risk by investigating the case of the Czech Republic. The mechanism of bank risk-taking coined by Borio and Zhu (2007) can be identified in studies on the credit channel, for instance Diamond and Rajan (2006) and Stiglitz and Greenwald (2003). Generally speaking, higher tolerance to risk implies that at times of low interest rates banks will seek to finance riskier borrowers. We focus on two aspects of the discussion, namely whether a monetary easing leads to more lending to borrowers with a riskier past and whether it encourages banks to extend new loans that default sooner. The two questions are vital both for macroprudential policy authorities and for academics due to their contradictory theoretical implications and their consequences for monetary policy design. We use Czech National Bank Credit Register data to model the probability of accepting borrowers with a bad credit history and the time to loan failure in association with a set of macroeconomic, firm, loan and bank characteristics. We ask two distinct research questions, employ two different measures of risk, and thus use two different econometric methodologies - an instrumental probit model and a duration model. Despite the fact that the analysis was done on one particular country, we strongly believe that the findings are transferable to other economies with a similar structure, i.e. small and open economies with independent monetary policy, reasonable economic fundamentals, and sound banking sector on the trajectory towards financial deepening.

The outcome of our probit analysis suggests that at times of monetary expansion Czech banks do not necessarily believe that the economic fundamentals are strong enough to reduce the default probability of borrowers with a recent bad credit history and are less likely to finance them. We provide a possible explanation for this - at first glance - puzzling result. The estimated influence of bank characteristics shows that larger and more liquid banks tend to extend fewer loans to firms with a recent bad credit history. Additionally, banks with a worse relative credit risk track record tend to finance fewer companies with a riskier past. Interestingly, we find that less leveraged banks are less likely to incur credit risk.

The result of our survival analysis indicates that relaxed monetary conditions promote risk-taking among banks. This outcome is confirmed irrespective of the way we address differences in bank profiles. Specifically, we obtain a positive association between low interest rates prior to loan origination and the loan hazard rate both when bank covariates are explicitly accounted for and when the effect of unobserved bank heterogeneity is estimated. Controlling for loan and borrower characteristics confirms that banks tend to extend loans with a higher hazard rate at times of monetary easing. Conditioning on the loan being extended, a lower interest rate during the loan life reduces its hazard rate. This result can be attributed to lower refinancing costs or, simply, a reduced 
loan repayment burden. We also found that the impact of monetary policy on risk-taking varies with bank characteristics. More liquid banks tend to grant less risky loans, which confirms one of the implications of Diamond and Rajan (2006).

The results of our analysis offer important policy lessons for the macroprudential policy of central banks, which - ideally - need to take into account the consequences of the monetary policy stance regarding bank risk-taking. The estimated parameters for interest rates, both prior to loan origination and during the life of the loan, enable us to quantify the potential effect of different interest rate paths on credit risk. The coefficient on the interest rate prior to loan origination varies in the survival models between -0.2 and -0.3 , with a standard error of around 0.15. For macroprudential purposes, it is recommended to be rather conservative. Assuming the highest (in absolute terms) coefficient plus two standard deviations implies that an interest rate decline of one percentage point increases the hazard rate by 0.6 percentage points. Thus, a substantial easing of monetary policy which would bring interest rates down from $5 \%$ (as in 2001-2002) quickly to $2 \%$ (as in 2004) could increase the hazard rates by almost 2 percentage points. The increase in the hazard rate would, however, happen under two conditions: (a) a worsening of the economic environment, such as an economic decline and an increase in retail interest rates, which would make it more difficult for borrowers to repay loans, (b) a worsening of economic the environment happening after a time of, say, at least one or two years, in order to "enable" new borrowers that took out loans in the period of rapid monetary easing to default on their obligations. Assuming that the hazard rates were in line with the default rates, which remained between $2 \%$ and $3 \%$ in 2007, just the risk-taking behaviour could increase the default rates by some 2 percentage points ${ }^{11}$ in addition to the effect of the economic decline and a possible increase in interest rates (i.e. debt servicing costs).

\section{References}

Y. Altunbas, L. Gambacorta, and D. Marques-Ibanez. Bank Risk and Monetary Policy. Working Papers 1075, European Central Bank, 2009.

Y. Altunbas, L. Gambacorta, and D. Marques-Ibanez. Does Monetary Policy Affect Bank Risk-Taking? mimeo 298, BIS Working Papers, 2010.

I. Babouček and M. Jančar. A VAR Analysis of the Effects of Macroeconomic Shocks to the Quality of the Aggregate Loan Portfolio of the Czech Banking Sector. CNB Working Paper Series 1, Czech National Bank, Research Department, 2005.

\footnotetext{
${ }^{11}$ To be precise, the figure would be 1.8 percentage points given a 3 percentage point drop in interest rates and a conservative change in the hazard rate of 0.6 percentage points.
} 
B. S. Bernanke and M. Gertler. Inside the Black Box: The Credit Channel of Monetary Policy Transmission. Journal of Economic Perspectives, 9(4): 27-48, 1995.

B. S. Bernanke, M. Gertler, and S. Gilchrist. The Financial Accelerator and the Flight to Quality. Review of Economics and Statistics, 78(1):1-15, 1996.

C. Borio and H. Zhu. Capital Regulation, Risk-taking and Monetary Policy: A Missing Link in the Transmission Mechanism. Mimeo, Bank for International Settlements, Basel, 2007.

J.H. Boyd and D.E. Runkle. Size and the Performance of Banking Firms: Testing the Predictions of theory. Journal of Monetary Economics, 31:46-47, 1993.

J. Campbell and J. Cochrane. By Force of Habit: A Consumption-Based Explanation of Aggregate Stock Market Behaviour. Journal of Political Economy, 107(107):205-251, 1999.

S. Chava and R. Jarrow. Bankruptcy Prediction with Industry Effects. Review of Finance, 8:537-69, 2004.

CNB. Financial Stability Report. Technical report, Czech National Bank, $2010 / 2011$.

D. Cox. Regression Models and Life-Tables. Journal of the Royal Statistical Society, 34(2):187-220, 1972.

G. Dell'Ariccia and R. Marquez. Lending Booms and Lending Standards. Journal of Finance, 61(5):2511-46, 2006.

D. W. Diamond. Financial Intermediation and Delegated Monitoring. Review of Economic Studies, 51:393-414, 1984.

D. W. Diamond and R. G. Rajan. Money in a Theory of Banking. American Economic Review, 96(1):30-53, 2006.

D. Duffie, L. Saita, and K. Wang. Multi-Period Corporate Default Prediction with Stochastic Covariates. Journal of Financial Economics, 83:635-665, 2007.

K. L. Finlay and M. Magnusson. Implementing Weak Instrument Robust Tests for a General Class of Instrumental Variables Models. Working Papers No. 0901, Tulane University, Department of Economics, Jan 2009.

A. Geršl and M. Hlaváček. Foreign Direct Investment and the Czech Corporate Sector: Potential Risks to Financial Stability. Financial stability report 2006, Czech National Bank, 2007. 
J. Glen and C. Mondragón-Vélez. Business Cycle Effects on Commercial Bank Loan Portfolio Performance in Developing Economies. Technical report, International Finance Corporation, World Bank Group, 2011.

R. G. Gutierrez. Parametric Frailty and Shared Frailty Survival Models. Stata Journal, 2(1):22-44, February 2002.

J. J. Heckmann and B. Singer. Econometric Duration Analysis. Journal of Econometrics, 24:63-132, 1984.

T. Hellman, K. Murdock, and J. E. Stiglitz. Liberalization, Moral Hazard in Banking and Prudential Regulation: Are Capital Controls Enough? American Economic Review, 90(1):147-65, 2000.

V. P. Ioannidou, S. Ongena, and J. L. Peydró-Alcalde. Monetary Policy and Subprime Lending: A Tall Tale of Low Federal Funds Rates, Hazardous Loans, and Reduced Loan Spreads. Mimeo, CentER-Tilburg University/European Central Bank, Tilburg, 2007.

V. P. Ioannidou, S. Ongena, and J. L. Peydró-Alcalde. Monetary Policy, RiskTaking and Pricing: Evidence from a Quasi-Natural Experiment. Technical report, CentER-Tilburg University, Tilburg, 2009.

P. Jakubík and C. Schmieder. Stress Testing Credit Risk: Is the Czech Republic Different from Germany? CNB Working Paper Series 9, Czech National Bank, 2008.

G. Jiménez, S. Ongena, J. L. Peydró-Alcalde, and J. Saurina. Hazardous Times for Monetary Policy: What Do Twenty-Three Million Bank Loans Say About the Effects of Monetary Policy on Credit Risk? CEPR Discussion Paper 6514, Banco de España, 2007.

G. Jiménez, S. Ongena, J. L. Peydró-Alcalde, and J. Saurina. Hazardous Times for Monetary Policy: What Do Twenty-Three Million Bank Loans Say About the Effects of Monetary Policy on Credit Risk-Taking? Working Papers 833, Banco de España, 2008.

N. Kadlčáková and J. Keplinger. Credit Risk and Bank Lending in the Czech Republic., 2004.

E. J. Kane. The SESL Insurance Mess: How Did It Happen? MIT Press, Cambridge, MA, 1989.

M. C. Keeley. Deposit Insurance, Risk, and Market Power in Banking. American Economic Review, 80(5):1183-1200, December 1990.

N. M. Kiefer. Economic duration data and hazard functions. Journal of Economic Literature, 26:646-679, 1988. 
Cara Lown and Donald P. Morgan. The Credit Cycle and the Business Cycle: New Findings Using the Loan Officer Opinion Survey. Journal of Money, Credit and Banking, 38(6):1575-1597, September 2006.

A. Maddaloni, J. L. Peydró-Alcalde, and S. Scope. Does Monetary Policy Affect Bank Credit Standards? Mimeo, European Central Bank, 2009.

H. M. Markowitz. Portfolio Selection. Journal of Finance, 7(1):77-91, 1952.

K. Matsuyama. Credit Traps and Credit Cycles. American Economic Review, 97(1):503-16, 2007.

M. Nkusu. Nonperforming Loans and Macrofinancial Vulnerabilities in Advanced Economies. Working Paper 11/161, IMF, 2011.

R. G. Rajan. Has Finance Made the World Riskier? European Financial Management, 12(4):499-533, 2006.

P. Royston and D. G. Altman. Regression Using Fractional Polynomials of Continuous Covariates: Parsimonious Parametric Modelling. Journal of the Royal Statistical Society, 43(3):429-467, 1994.

T. Shumway. Forecasting Bankruptcy More Accurately: A Simple Hazard Model. Journal of Business, 74:101-24, 2001.

B. D. Smith. Monetary Policy, Banking Crises, and the Friedman Rule. American Economic Review, 92(2):128-34, 2002.

J. E. Stiglitz and B. Greenwald. Towards a New Paradigm in Monetary Economics. Cambridge University Press, 2003.

A. Stomper. A Theory of Banks' Industry Expertise, Market Power, and Credit Risk. Management Science, 52(10):1618-1634, 2006.

M. Čihák and J. Heřmánek. Stress Testing the Czech Banking System: Where Are We? Where Are We Going?, 2005. 


\section{Appendix A}

Table A1: Definitions of Variables

\begin{tabular}{|c|c|}
\hline Variable & Definition \\
\hline Interest rate $_{t-1}$ & $\begin{array}{l}\text { Monthly average of euro overnight interest rate for month prior to loan ori- } \\
\text { gination }\end{array}$ \\
\hline $\mathrm{GDPCR}_{t-1}$ & $\begin{array}{l}\text { Rate of change of gross domestic product, chain-linked working day and sea- } \\
\text { sonally adjusted, quarterly frequency }\end{array}$ \\
\hline $\mathrm{CPI}_{t}$ & Monthly indices of consumer prices \\
\hline Country risk $t$ & $\begin{array}{l}\text { Long-term interest rate spread between Czech } 10 \text {-year maturity government } \\
\text { bond yield and EMU 10-year maturity T-bond yield, both yields expressed } \\
\text { as monthly averages and in per cent }\end{array}$ \\
\hline Bank size $_{t-1}$ & $\begin{array}{l}\text { Natural logarithm of bank total assets measured } 1 \text { month prior to loan ori- } \\
\text { gination }\end{array}$ \\
\hline Liquidity ratio $_{t-1}$ & $\begin{array}{l}\text { Amount of bank liquid assets over total assets measured } 1 \text { month prior to } \\
\text { loan origination }\end{array}$ \\
\hline Bank NPL $L_{b}-\mathrm{NPL}_{t-1}$ & $\begin{array}{l}\text { Difference between bank and other banks' level of NPLs measured } 1 \text { month } \\
\text { prior to loan origination }\end{array}$ \\
\hline Own funds/total assets $t-1$ & $\begin{array}{l}\text { Bank's equity amount over bank's total assets measured } 1 \text { month prior to } \\
\text { loan origination }\end{array}$ \\
\hline Bank type $_{t-1}$ & $=1$ if bank is foreign owned \\
\hline $\ln (2+\text { age as borrower })_{t-1}$ & $\begin{array}{l}\text { Natural logarithm of number of years (augmented by } 2 \text { and measured } 1 \text { month } \\
\text { prior to loan origination) that have elapsed since first time firm borrowed from } \\
\text { bank }\end{array}$ \\
\hline Bank relations $t-1$ & $\begin{array}{l}\text { Natural logarithm of number of bank relationships of borrower plus } 1 \text { meas- } \\
\text { ured prior to loan origination }\end{array}$ \\
\hline Bank debt $t-1$ & $\begin{array}{l}\text { Natural logarithm of borrower bank debt plus } 1 \text { measured prior to loan ori- } \\
\text { gination }\end{array}$ \\
\hline Loan size $t$ & Natural logarithm of loan amount \\
\hline Maturity $0-6$ monthst & $=1$ if loan maturity is less than or equal to 6 months \\
\hline Maturity $6-12$ months $t$ & $=1$ if loan maturity is between 6 and 12 months \\
\hline Maturity $12-18$ months $_{t}$ & $=1$ if loan maturity is between 1 and 1.5 year \\
\hline Loan currencyt & $=1$ if loan is granted in euros, dollars or pounds \\
\hline Loan purpose $t$ & $=1$ if overdrafts or current account debit \\
\hline Firm turnover categories & Dummy variables created for CNB categories of firm turnover in CZK million \\
\hline Firm employment categories & Dummy variables created for CNB categories of number of firm employees \\
\hline
\end{tabular}


Table A2: Correlations Between Variables

\begin{tabular}{|c|c|c|c|c|c|c|c|c|c|c|c|c|c|c|}
\hline Variable & {$[1]$} & {$[2]$} & [3] & {$[4]$} & [5] & [6] & [7] & [8] & [9] & [10] & [11] & [12] & [13] & \\
\hline $\begin{array}{l}\text { Interest } \\
\text { rate }_{t-1}\end{array}$ & 1.00 & & & & & & & & & & & & & \\
\hline $\begin{array}{l}\text { Interest } \\
\text { rate }_{T-t-1}\end{array}$ & 0.09 & 1.00 & & & & & & & & & & & & \\
\hline $\mathrm{GDPCR}_{t-1}$ & 0.25 & 0.35 & 1.00 & & & & & & & & & & & \\
\hline $\mathrm{GDPCR}_{T-t-1}$ & -0.24 & 0.64 & 0.23 & 1.00 & & & & & & & & & & \\
\hline $\mathrm{CPI}_{t}$ & 0.52 & -0.11 & 0.06 & -0.34 & 1.00 & & & & & & & & & \\
\hline Bank size $_{t-1}$ & 0.10 & -0.06 & 0.02 & -0.10 & 0.14 & 1.00 & & & & & & & & \\
\hline $\begin{array}{l}\text { Liquidity } \\
\text { ratio }_{t-1}\end{array}$ & -0.24 & 0.06 & 0.11 & 0.18 & -0.26 & 0.44 & 1.00 & & & & & & & \\
\hline $\begin{array}{l}\text { Bank NPL } \mathrm{N}_{b}- \\
\mathrm{NPL}_{t-1}\end{array}$ & -0.05 & -0.00 & 0.05 & 0.01 & -0.03 & -0.04 & 0.07 & 1.00 & & & & & & \\
\hline $\begin{array}{l}\text { Own } \\
\text { funds } s_{t-1}\end{array}$ & -0.12 & -0.00 & 0.03 & 0.07 & -0.09 & -0.19 & 0.13 & 0.16 & 1.00 & & & & & \\
\hline $\begin{array}{l}\ln (2+\text { age as } \\
\text { borrower })_{t-1}\end{array}$ & 0.00 & -0.01 & -0.02 & 0.02 & 0.06 & 0.05 & -0.02 & -0.01 & -0.03 & 1.00 & & & & \\
\hline $\begin{array}{l}\text { Bad } \\
\text { history }_{t-1}\end{array}$ & 0.10 & 0.01 & -0.05 & -0.02 & 0.09 & -0.07 & -0.18 & -0.05 & -0.03 & 0.21 & 1.00 & & & \\
\hline $\begin{array}{l}\text { Bank } \\
\text { relations } t-1\end{array}$ & -0.09 & 0.01 & -0.04 & 0.10 & -0.12 & -0.06 & 0.06 & -0.01 & 0.06 & 0.55 & 0.20 & 1.00 & & \\
\hline $\begin{array}{l}\text { Bank } \\
\text { debt }_{t-1}\end{array}$ & -0.10 & -0.02 & -0.09 & 0.09 & -0.14 & -0.06 & 0.04 & -0.02 & 0.05 & 0.48 & 0.16 & 0.84 & 1.00 & \\
\hline Loan $\operatorname{size}_{t}$ & -0.01 & -0.01 & 0.01 & 0.01 & -0.01 & -0.05 & -0.06 & 0.01 & -0.07 & 0.27 & 0.08 & 0.22 & 0.26 & 1.00 \\
\hline
\end{tabular}

Table A3: Weak Instrument Robust Tests for IV Probit

\begin{tabular}{l||cc}
\hline \hline Test & Statistic & p-value \\
\hline AR & $\chi_{(1)}^{2}=165.66$ & Prob $>\chi_{(1)}^{2}=0.0000$ \\
\hline Wald & $\chi_{(1)}^{2}=165.31$ & Prob $>\chi_{(1)}^{2}=0.0000$ \\
\hline \hline
\end{tabular}


Table A4: Estimation Results for Probit Model with Clustered Loans

\begin{tabular}{|c|c|c|}
\hline Variable & Coefficient & Robust Std. Err. \\
\hline Interest rate $_{t-1}$ & $0.079^{* * *}$ & 0.030 \\
\hline Bank size $_{t-1}$ & -0.032 & 0.027 \\
\hline Liquidity ratio $t-1$ & $-1.862^{* * *}$ & 0.199 \\
\hline Bank $\mathrm{NPL}_{b}-\mathrm{NPL}_{t-1}$ & $-0.713^{*}$ & 0.377 \\
\hline Own funds/total assets $t-1$ & 0.143 & 0.429 \\
\hline Bank type $_{t-1}$ & $0.150^{*}$ & 0.081 \\
\hline $\ln (2+\text { age as borrower })_{t-1}$ & $0.163^{* * *}$ & 0.021 \\
\hline Bank relations $s_{t-1}$ & $0.759^{* * *}$ & 0.076 \\
\hline Bank debt $t_{t-1}$ & $-0.015^{* * *}$ & 0.004 \\
\hline Loan size $t$ & $0.019^{* *}$ & 0.009 \\
\hline Loan $_{\text {currency }} t$ & $0.236^{* * *}$ & 0.064 \\
\hline Maturity $0-3$ months $_{t}$ & $0.331^{* * *}$ & 0.037 \\
\hline Maturity 3-6 months $_{t}$ & $0.241^{* * *}$ & 0.042 \\
\hline Maturity $6-12$ months $_{t}$ & $0.246^{* * *}$ & 0.037 \\
\hline Loan purpose $t$ & $-0.082^{* *}$ & 0.038 \\
\hline $\mathrm{GDPCR}_{t-1}$ & $-0.031^{* * *}$ & 0.008 \\
\hline $\mathrm{CPI}_{t}$ & 0.006 & 0.013 \\
\hline Country risk $t$ & 0.037 & 0.072 \\
\hline Time trend & $0.014^{* * *}$ & 0.002 \\
\hline Time trend sq. & $0.000^{* * *}$ & 0.000 \\
\hline Intercept & $-1.342^{* * *}$ & 0.334 \\
\hline Collateral dummies & & yes \\
\hline Firm turnover categories & & yes \\
\hline Firm employment categories & & yes \\
\hline Firm regional dummies & & yes \\
\hline Firm industry dummies & & yes \\
\hline $\mathrm{N}$ & & 205,270 \\
\hline Log-likelihood & & $-98,985.748$ \\
\hline$\chi_{(67)}^{2}$ & & $1,126.521$ \\
\hline
\end{tabular}




\section{Appendix B}

This section describes the steps involved in building the optimal survival and probit models developed as a robustness check for our probit and loan survival analysis. In the probit analysis we first evaluate the significance of each potential measure by considering its univariate probit fit. All covariates with p-values less than $25 \%$ along with all those of known economic importance are initially included in the multivariable model. Following the fit of the initial model we verify the significance of each variable in the model to identify those which can be removed. In order to nominate covariates that might be deleted from the model we use the p-values from the Wald tests of the individual coefficients, and then examine the p-value of the partial likelihood ratio test to confirm that the deleted covariate is indeed not significant. Having eliminated all insignificant measures at this stage, we coarsely classify the discrete characteristics overly rich in their categories, such as the 72 firm regional affiliations. We fit a hazard model for each category and group the characteristics with similar parameter estimates and significance levels. Thereafter, we employ the method of fractional polynomials to suggest transformations of the continuous variables. To ensure the economic validity of the transformed continuous covariates, we limit our search for proper functional forms to the natural logarithm and powers of plus and minus one. Moreover, we use the fractional polynomials procedure as a tool for validating the variables' significance once the optimal transformations have been incorporated. Finally, we determine whether our model necessitates interaction terms. We test the significance at the $5 \%$ level of all economically plausible interaction terms formed from the main effects in our model. As previously, we examine the p-values from the Wald test and the partial likelihood ratio test.

To select the covariates for the survival analysis we employ essentially the same methods as those used in the probit regression. We begin with the bivariate analysis of the association between all plausible variables and the loan survival time. For all potential predictors we compute the first, fifth, tenth, fifteenth and twentieth percentiles of the survival times. No estimates of higher survival quantiles are needed, as the loan data are typically characterized by low default occurrence. In our dataset the default ratio does not exceed $20 \%$ in specific subgroups and is approximately $2 \%$ on average. For descriptive purposes, we break continuous variables into ten and twenty quantiles and compare the survivorship experience across the groups so defined. We examine the equality of the survivor functions using a set of available non-parametric tests, but we mostly rely on the log-rank test. Additionally, we consider the partial likelihood ratio test obtained in the estimation of each covariate's group-specific impact on the time to loan failure. Evidently, the same type of bivariate analysis is performed for categorical predictors. All variables with log-rank and partial likelihood ratio test p-values less than $20 \%$ along with all those that are economically vital are initially included in the multivariable model. Thereafter, we repeat all the steps already described for the probit variable selection. We fit the initial model, 
remove insignificant covariates, coarsely classify the discrete characteristics and apply the method of fractional polynomials to the multivariable proportional hazards regression model. Next, we determine whether any economically plausible interaction terms need to be added. Finally, we check the model's validity and its adherence to the proportionality assumption.

The methodology of fractional polynomials due to Royston and Altman (1994) offers an analytical way of determining the scale of the continuous predictors. Royston and Altman (1994) introduce a family of curves called fractional polynomials with power terms limited to a small predefined set of values and show how to find the best powers yielding the best-fitting and parsimonious model. In a single covariate case, a fractional polynomial of degree $m$ is defined as:

$$
\phi_{m}(X ; \xi, p)=\xi_{0}+\sum_{j=1}^{m} \xi_{j} X^{p_{j}}
$$

where $m$ is a positive integer, $p=\left(p_{1}, \ldots, p_{m}\right)$ is a vector of powers with $p_{1}$ $<\ldots<p_{m}, \xi=\left(\xi_{0}, \xi_{1}, \ldots, \xi_{m}\right)$ are coefficients and $X^{p_{j}}$ signifies:

$$
X^{p_{j}}=\left\{\begin{array}{ccc}
X^{p_{j}} & \text { if } & p_{j} \neq 0 \\
\ln (X) & \text { if } & p_{j}=0
\end{array}\right.
$$

Expressions B.1 and B.2 combined and generalized can be rewritten into:

$$
\begin{array}{r}
\phi_{m}(X ; \xi, p)=\sum_{j=0}^{m} \xi_{j} H_{j}(X) \\
H_{j}(X)=\left\{\begin{array}{cc}
X^{p_{j}} & \text { if } p_{j} \neq p_{j-1} \\
H_{j-1}(X) \ln (X) & \text { if } p_{j}=p_{j-1}
\end{array}\right.
\end{array}
$$

Royston and Altman (1994) advocate that $p=\{-2,-1,-0.5,0,0.5,1,2,3\}$ is a set of powers sufficiently rich to handle many practical cases. The best model is the one with the largest log likelihood. We use the fractional polynomials routine extended for multivariable specifications and implemented in STATA. An iterative search of scale within multivariable models involves checking for the scale of each covariate. To briefly illustrate the process, let's consider $m=2$. For each variable the routine tests the best $J=2$ model versus the linear model, the best $J=2$ versus the best $J=1$ fractional polynomial model and the linear model versus the model excluding the tested covariate. Having checked each 
predictor, the procedure repeats for each variable using the outcome of the first cycle for all covariates other than the one currently being tested in the second cycle. The reiteration aims to ascertain whether changing the functional form of one covariate alters the transformation of the other covariates. The routine runs until no further transformation is suggested. Table $B 1$ contains the definitions of the optimally chosen covariates, while tables $B 2-B 4$ present their descriptive statistics.

Table B1: Robust Specification: Definitions of Variables

\begin{tabular}{|c|c|}
\hline Variable & Definition \\
\hline Deposit ratio $_{t-1}$ & $\begin{array}{l}\text { Amount of bank's deposits over bank's total assets measured } 1 \text { month prior } \\
\text { to loan origination }\end{array}$ \\
\hline Bank type $t-1$ & $\begin{array}{l}=1 \text { if bank is branch in } \mathrm{CZ} \text { (as opposed to headquarters in } \mathrm{CZ} \text { or branch } \\
\text { abroad) }\end{array}$ \\
\hline Probit: Maturity $2-3.5$ year & $=1$ if loan maturity is between 2 and 3.5 years \\
\hline Probit: Maturity $4-8$ years & $=1$ if loan maturity is between 4 and 8 years but not 5.5 years \\
\hline $1^{\text {st }}$ collateral: $[1]$ & $=1$ if none or $3^{r d}$ party real estate \\
\hline $1^{\text {st }}$ collateral: $[2]$ & $=1$ if guarantee deposits or real estate \\
\hline $1^{\text {st }}$ collateral: [3] & $=1$ if movable property with ownership transfer \\
\hline $1^{\text {st }}$ collateral: $[4]$ & $=1$ if pledged securities \\
\hline $2^{\text {nd }}$ collateral: $[1]$ & $=1$ if real estate or movable property without ownership transfer \\
\hline $2^{\text {nd }}$ collateral: $[5]$ & $=1$ if other collateral \\
\hline $3^{r d}$ collateral: $[1]$ & $=1$ if real estate or movable property without ownership or guarantee deposit \\
\hline $3^{\text {rd }}$ collateral: $[2]$ & $=1$ if pledged assets or ensuring notes or other \\
\hline $3^{\text {rd }}$ collateral: $[3]$ & $=1$ if guarantee (incl. bank guarantee) or blockage of premium \\
\hline Loan purpose: [1] & $=1$ if temporary shortage of resources or residential property \\
\hline Loan purpose: [2] & $\begin{array}{l}=1 \text { if residential property for business purposes, overdrafts or debit, other } \\
\text { investment loans }\end{array}$ \\
\hline Loan purpose: [3] & $=1$ if residential property without state aid \\
\hline Loan purpose: [4] & $=1$ if purchase of securities \\
\hline Loan purpose: [5] & $=1$ if seasonal costs or subordinated loans \\
\hline Loan currency & $=1$ if loan granted in Czech or Slovak koruna or Japanese yen \\
\hline
\end{tabular}


Table B2: Robust Probit Model: Data Descriptive Statistics

\begin{tabular}{|c|c|c|c|c|c|c|}
\hline Variable & Unit & Mean & Std. & Dev. & Max & Min \\
\hline Interest rate $_{t-1}$ & $\%$ & 2.74 & & 0.88 & 4.30 & 0.35 \\
\hline $\mathrm{GDPCR}_{t-1}$ & $\%$ & 4.77 & & 2.58 & 7.70 & -4.70 \\
\hline $\mathrm{CPI}_{t}$ & $\%$ & 2.59 & & 1.85 & 7.50 & -0.40 \\
\hline Country risk $_{t}$ & $\%$ & 0.13 & & 0.34 & 1.26 & -0.38 \\
\hline Bank relations $_{t-1}$ & \# & 0.32 & & 0.41 & 1.80 & 0.00 \\
\hline $\ln (2+\text { age as borrower })_{t-1}$ & $\#$ & 2.17 & & 1.06 & 4.00 & 1.00 \\
\hline Bad history $_{t-1}$ & $0 \mid 1$ & 0.08 & & 0.27 & 1.00 & 0.00 \\
\hline Bank size $_{t-1}$ & CZK & 12.45 & & 1.16 & 13.59 & 5.33 \\
\hline Liquidity ratio $t-1$ & $\%$ & 0.32 & & 0.13 & 0.71 & 0.00 \\
\hline Bank $\mathrm{NPL}_{b}-\mathrm{NPL}_{t-1}$ & $\%$ & 0.02 & & 0.07 & 6.40 & -0.12 \\
\hline Own funds/total assets $_{t-1}$ & $\%$ & 0.09 & & 0.05 & 0.61 & -0.08 \\
\hline Deposit ratio $_{t-1}$ & $\%$ & 0.66 & & 0.11 & 0.98 & 0.00 \\
\hline Bank type $_{t-1}$ & $0 \mid 1$ & 0.67 & & 0.47 & 1.00 & 0.00 \\
\hline Loan size $_{t}$ & CZK & 14.55 & & 2.00 & 22.69 & 0.00 \\
\hline Maturity $2-3.5$ year & $0 \mid 1$ & 0.17 & & 0.38 & 1.00 & 0.00 \\
\hline Maturity $4-8$ years & $0 \mid 1$ & 0.25 & & 0.43 & 1.00 & 0.00 \\
\hline Maturity 5.5 year & $0 \mid 1$ & 0.02 & & 0.13 & 1.00 & 0.00 \\
\hline Maturity $8.5-10$ years & $0 \mid 1$ & 0.04 & & 0.20 & 1.00 & 0.00 \\
\hline Loan $_{\text {currency }} t$ & $0 \mid 1$ & 0.95 & & 0.22 & 1.00 & 0.00 \\
\hline
\end{tabular}

Table B3: Robust Survival Model: Data Descriptive Statistics

\begin{tabular}{|c|c|c|c|c|c|}
\hline Variable & Unit & Mean & Std. Dev. & Max & Min \\
\hline Interest rate $_{t-1}$ & $\%$ & 2.74 & 0.88 & 4.30 & 0.35 \\
\hline Interest rate $_{T-t-1}$ & $\%$ & 2.39 & 1.34 & 4.30 & 0.34 \\
\hline $\mathrm{GDPCR}_{t-1}$ & $\%$ & 4.77 & 2.58 & 7.70 & -4.70 \\
\hline $\operatorname{GDPCR}_{T-t-1}$ & $\%$ & 2.55 & 3.86 & 7.70 & -4.70 \\
\hline $\mathrm{CPI}_{t}$ & $\%$ & 2.59 & 1.85 & 7.50 & -0.40 \\
\hline Country risk $_{t}$ & $\%$ & 0.13 & 0.34 & 1.26 & -0.38 \\
\hline Bank size $_{t-1}$ & CZK & 12.45 & 1.16 & 13.59 & 5.33 \\
\hline Liquidity ratio $t-1$ & $\%$ & 0.32 & 0.13 & 0.71 & 0.00 \\
\hline Own funds to total assets $t_{t-1}$ & $\%$ & 0.09 & 0.05 & 0.61 & -0.08 \\
\hline $\mathrm{CAR}_{t-1}$ & $\%$ & 12.36 & 7.56 & 147.14 & 0.00 \\
\hline $\mathrm{CAR}_{t-1}^{-1}$ & $\%$ & 0.08 & 0.02 & 0.12 & 0.01 \\
\hline Bank profit $_{t-1}$ & $\mathrm{CZK}$ & 0.48 & 0.55 & 12.22 & -4.68 \\
\hline Bank type $_{t-1}$ & $0 \mid 1$ & 0.67 & 0.47 & 1.00 & 0.00 \\
\hline $\ln (2+\text { age as borrower })_{t-1}$ & $\#$ & 2.17 & 1.06 & 4.00 & 1.00 \\
\hline Bad history ${ }_{t-1}$ & $0 \mid 1$ & 0.08 & 0.27 & 1.00 & 0.00 \\
\hline Loan $_{\text {size }}$ & CZK & 14.55 & 2.00 & 22.69 & 0.00 \\
\hline Maturity 0-6 months $_{t}$ & $0 \mid 1$ & 0.04 & 0.19 & 1.00 & 0.00 \\
\hline Maturity $6-12$ months $_{t}$ & $0 \mid 1$ & 0.06 & 0.23 & 1.00 & 0.00 \\
\hline Maturity $12-18$ months $_{t}$ & $0 \mid 1$ & 0.22 & 0.41 & 1.00 & 0.00 \\
\hline Loan purpose $_{t}$ & $0 \mid 1$ & 0.30 & 0.46 & 1.00 & 0.00 \\
\hline Herfindahl-Hirschman index $t$ & $\#$ & 0.48 & 1.07 & 6.40 & 0.00 \\
\hline
\end{tabular}


Table B4: Robust Models: Correlations Between Variables

\begin{tabular}{|c|c|c|c|c|c|c|c|c|c|c|c|c|c|c|}
\hline Variable & [1] & [2] & [3] & [4] & [5] & [6] & {$[7]$} & [8] & [9] & [10] & [11] & [12] & [13] & [14] \\
\hline Interest & 1.00 & & & & & & & & & & & & & \\
\hline Interest & 0.07 & 1.00 & & & & & & & & & & & & \\
\hline $\operatorname{rate}_{T-t-1}$ & & & & & & & & & & & & & & \\
\hline $\mathrm{GDP}_{t-1}$ & 0.23 & 0.36 & 1.00 & & & & & & & & & & & \\
\hline $\operatorname{GDP}_{T-t-1}$ & -0.27 & 0.64 & 0.23 & 1.00 & & & & & & & & & & \\
\hline $\mathrm{CPI}_{t}$ & 0.52 & -0.13 & 0.05 & -0.37 & 1.00 & & & & & & & & & \\
\hline $\begin{array}{l}\text { Country } \\
\text { risk }_{t}\end{array}$ & -0.42 & -0.20 & -0.44 & -0.09 & 0.28 & 1.00 & & & & & & & & \\
\hline Bank size $_{t-1}$ & 0.09 & -0.08 & 0.00 & -0.15 & 0.17 & 0.01 & 1.00 & & & & & & & \\
\hline $\begin{array}{l}\text { Liquidity } \\
\text { ratio }_{t-1}\end{array}$ & -0.29 & 0.05 & 0.09 & 0.19 & -0.29 & -0.02 & 0.37 & 1.00 & & & & & & \\
\hline $\begin{array}{l}\text { Own } \\
\text { funds } s_{t-1}\end{array}$ & -0.12 & -0.02 & -0.01 & 0.05 & -0.07 & 0.01 & -0.46 & 0.05 & 1.00 & & & & & \\
\hline $\mathrm{CAR}_{t-1}$ & -0.15 & -0.02 & -0.14 & 0.08 & -0.18 & 0.04 & -0.47 & 0.21 & 0.78 & 1.00 & & & & \\
\hline Loan $\operatorname{size}_{t}$ & -0.02 & -0.01 & 0.01 & 0.01 & -0.02 & 0.02 & -0.01 & -0.06 & -0.04 & -0.02 & 1.00 & & & \\
\hline $\begin{array}{l}\text { Bad } \\
\text { history }\end{array}$ & 0.04 & 0.01 & -0.01 & 0.03 & 0.00 & -0.02 & -0.02 & -0.03 & 0.05 & 0.02 & 0.10 & 1.00 & & \\
\hline Borrower & 0.00 & -0.01 & -0.01 & 0.02 & 0.06 & 0.04 & 0.10 & -0.02 & -0.00 & -0.05 & 0.28 & 0.29 & 1.00 & \\
\hline $\begin{array}{l}\operatorname{age}_{t-1} \\
\text { Bank } \\
\text { profit }_{t-1}\end{array}$ & 0.00 & -0.07 & 0.00 & -0.07 & 0.11 & 0.04 & 0.46 & 0.24 & -0.07 & -0.10 & -0.00 & -0.00 & 0.09 & 1.00 \\
\hline
\end{tabular}


Table B5: Estimation Results for Robust Probit Model with Clustered Loans

\begin{tabular}{|c|c|c|}
\hline Variable & Coefficient & Robust Std. Err. \\
\hline Interest rate $_{t-1}$ & $0.237^{* * *}$ & 0.048 \\
\hline $\ln (2+\text { age as borrower })_{t-1}$ & $0.402^{* * *}$ & 0.032 \\
\hline Bank relations $t-1$ & $1.438^{* * *}$ & 0.089 \\
\hline Bank size $_{t-1}$ & -0.042 & 0.041 \\
\hline Liquidity ratio $t-1$ & $-0.981^{* * *}$ & 0.291 \\
\hline Bank $\mathrm{NPL}_{b}-\mathrm{NPL}_{t-1}$ & -1.424 & 0.935 \\
\hline Own funds/total $\operatorname{assets}_{t-1}$ & -0.550 & 0.727 \\
\hline Deposit ratio $t-1$ & $1.285^{* * *}$ & 0.387 \\
\hline Bank type $_{t-1}$ & $-0.237^{* * *}$ & 0.068 \\
\hline Maturity $2-3.5$ years $t$ & -0.072 & 0.060 \\
\hline Maturity $4-8$ years $_{t}$ & $-0.296^{* * *}$ & 0.074 \\
\hline Maturity 5.5 years $_{t}$ & $0.355^{*}$ & 0.200 \\
\hline Maturity 8.5-10 years $_{t}$ & -0.166 & 0.154 \\
\hline Loan currency $_{t}$ & $-0.159^{*}$ & 0.093 \\
\hline $\mathrm{GDPCR}_{t-1}$ & -0.019 & 0.012 \\
\hline $\mathrm{CPI}_{t}$ & $-0.089^{* * *}$ & 0.021 \\
\hline Country risk $t$ & 0.161 & 0.116 \\
\hline Time trend & $0.011^{* * *}$ & 0.004 \\
\hline Time trend sq. & $0.000^{* *}$ & 0.000 \\
\hline Intercept & $-3.275^{* * *}$ & 0.416 \\
\hline Collateral & & yes \\
\hline Loan purpose & & yes \\
\hline Firm turnover categories & & yes \\
\hline Firm employment categories & & yes \\
\hline Firm regional dummies & & yes \\
\hline Firm industry dummies & & yes \\
\hline $\mathrm{N}$ & & 207,352 \\
\hline Log-likelihood & & $7,066.548$ \\
\hline$\chi_{(67)}^{2}$ & &, 475.642 \\
\hline
\end{tabular}

Table B6: Robust Probit Results for Firm Turnover Controls

\begin{tabular}{lcc}
\hline \hline Firm turnover in CZK millions & Coefficient & Robust Std. Err. \\
\hline$<0.2$ or $\geq 1500$ & $-0.911^{* * *}$ & 0.126 \\
$\langle 0.2,0.5),(10,30),\langle 200,300)$ & $-0.595^{* * *}$ & 0.098 \\
$\langle 0.5,1),\langle 30,60)$ & $-0.657^{* * *}$ & 0.121 \\
$\langle 500,1000)$ & -0.114 & 0.074 \\
$\langle 100,200),\langle 1000,1500)$ & -0.074 & 0.077 \\
\hline
\end{tabular}

Table B7: Robust Probit Results for Firm Employment Controls

\begin{tabular}{lcc}
\hline \multicolumn{1}{c}{ Firm employment } & Coefficient & Robust Std. Err. \\
\hline$\langle 1500,1999)$ & $-1.186^{* * *}$ & 0.271 \\
$\langle 6,9),\langle 50,99),\langle 250,499)$ & $-0.379^{* * *}$ & 0.093 \\
$\langle 1,5),\langle 10,19),\langle 25,49)$ & $-0.260^{* * *}$ & 0.086 \\
$\langle 20,24),\langle 100,199)$ & $-0.354^{* * *}$ & 0.103 \\
$\langle 500,999)$ & $0.284^{* *}$ & 0.125 \\
$\langle 1000,499)$ & $1.008^{* *}$ & 0.507 \\
\hline
\end{tabular}


Table B8: Robust Probit Estimation Results for Loan Collateral Types

\begin{tabular}{lcc}
\hline \hline \multicolumn{1}{c}{ Variable } & Coefficient & Robust Std. Err. \\
\hline $1^{\text {st }}$ collateral & & \\
None or $3^{r d}$ party real estate & $-0.153^{* * *}$ & 0.057 \\
Guarantee deposits or real estate & $-0.412^{* * *}$ & 0.081 \\
Movable property with ownership transfer & $-0.960^{* * *}$ & 0.326 \\
Securities & $1.074^{* *}$ & 0.493 \\
$2^{\text {nd } \text { collateral }}$ & & \\
Real estate or movable property w/o ownership transfer & $-0.255^{* * *}$ & 0.093 \\
Movable property with ownership transfer & $0.769^{* *}$ & 0.312 \\
Securities & $-0.159^{* *}$ & 0.062 \\
State guarantee & $-1.117^{* * *}$ & 0.405 \\
Other collateral & $-0.479^{* * *}$ & 0.141 \\
$3^{r d}$ collateral & & \\
Real estate or movable property w/o ownership or deposit & $0.495^{* * *}$ & 0.169 \\
Assets or ensuring notes or other & 0.197 & 0.133 \\
Guarantee (incl. bank guarantee) or blockage of premium & 0.226 & 0.199 \\
\hline
\end{tabular}

Table B9: Robust Probit Estimation Results for Loan Purpose

\begin{tabular}{lcc}
\hline \hline \multicolumn{1}{c}{ Loan purpose } & Coefficient & Robust Std. Err. \\
\hline $\begin{array}{l}\text { Temporary shortage of resources or residential prop- } \\
\text { erty }\end{array}$ & $-0.591^{* * *}$ & 0.201 \\
$\begin{array}{l}\text { Residential property for business purposes, overdrafts } \\
\text { or debit, other investment loans }\end{array}$ & $-0.104^{*}$ & 0.057 \\
Residential property w/o state aid & $0.331^{*}$ & 0.198 \\
Purchase of securities & $1.031^{* *}$ & 0.434 \\
Seasonal costs or subordinated loans & $0.960^{* * *}$ & 0.285 \\
\hline
\end{tabular}

